\title{
Lessons from the Electric Vehicle Crashworthiness Leading to Battery Fire
}

\author{
Pius Victor Chombo ${ }^{1,2}\left(\mathbb{D}\right.$, Yossapong Laoonual ${ }^{2,3} \mathbb{\infty}$ and Somchai Wongwises ${ }^{3,4, *}$ \\ 1 The Joint Graduate School of Energy and Environment, King Mongkut's University of Technology Thonburi, \\ Bangmod, Bangkok 10140, Thailand; piusvictor2016@gmail.com \\ 2 Mobility \& Vehicle Technology Research Center (MOVE), King Mongkut's University of Technology \\ Thonburi, Bangmod, Bangkok 10140, Thailand; yossapong.lao@mail.kmutt.ac.th \\ 3 Department of Mechanical Engineering, Faculty of Engineering, King Mongkut's University of Technology \\ Thonburi, Bangmod, Bangkok 10140, Thailand \\ 4 National Science and Technology Development Agency (NSTDA), Pathum Thani 12120, Thailand \\ * Correspondence: somchai.won@kmutt.ac.th
}

Citation: Victor Chombo, P.;

Laoonual, Y.; Wongwises, S. Lessons from the Electric Vehicle Crashworthiness Leading to Battery Fire. Energies 2021, 14, 4802. https:// doi.org/10.3390/en14164802

Academic Editor:

Cheol-Hong Hwang

Received: 17 March 2021

Accepted: 24 May 2021

Published: 6 August 2021

Publisher's Note: MDPI stays neutral with regard to jurisdictional claims in published maps and institutional affiliations.

Copyright: (c) 2021 by the authors. Licensee MDPI, Basel, Switzerland. This article is an open access article distributed under the terms and conditions of the Creative Commons Attribution (CC BY) license (https:// creativecommons.org/licenses/by/ $4.0 /)$
Abstract: Electric vehicles (EVs) are currently emerging as alternative vehicles due to their high energy efficiency and low emissions during driving. However, regarding the raising concern, the safety of EVs can further be improved before they completely replace conventional vehicles. This paper focuses on reviewing the safety requirements of EVs, especially those powered by Li-ion battery, based on the mechanical abuse tests from the international standards, national standards, regulations and other laboratories standards, and safety of occupants from the regulations and safety programs. Moreover, the publicly reported real-world fire incidents of EVs based on road crashes were collected and reviewed. The objective is to highlight the gap and challenges arose between the current safety requirements and real-world fire incidents of EVs and provide the way for assisting the future research in the area of EV safety, particularly light duty passenger vehicle. The serious challenges observed include high impact speed, multi-crashes per incident, multiple barriers of different types involved in the accident, and post-crash safety (serious injury and demise) of occupants and rescue teams. While addressing these challenges, this review will aid researchers and manufacturers working in batteries, EVs, and fire safety engineering to narrow the gap and enhance the safety of future EVs in areas of battery materials, fire extinguishing, and vehicle's body structure.

Keywords: electric vehicle; crashworthiness; EVs' fire incidents; safety programs; regulations

\section{Introduction}

Currently, the strict environmental constraints have made the transport sector focus on the clean technologies to reduce emissions in the environment [1]. In this context, electric vehicles (EVs) have emerged as a promising solution to reduce the tank-to-wheel emissions in the road transport [2] as they offer a zero emission in the driving mode [3-5]. Besides, EVs have higher tank-to-wheel efficiency of about $60 \%$ to $80 \%$ compared to $20 \%$ to $35 \%$ [6] of conventional vehicles and lower recharge cost as electricity is cheaper than petrol/diesel fuels.

A few years ago, the automotive industry experienced an evolution of advanced EVs such as battery electric vehicles (BEVs), hybrid electric vehicles (HEVs), plug-in hybrid electric vehicles (PHEVs), and fuel cell vehicles (FCVs) [7]. In addition to that, EVs have showed an uptrend in both demand and production [8-10] incorporating Lithium-ion battery technologies for storing electrical energy and propulsion of EVs. The success of EV market is strongly attributed by implementation of clean energy/air policy [8,9] (e.g., C40 policy for world's megacities to adopt EV technologies in bus, taxis, and other citywide fleets [10-13]) and improved technologies (energy efficient motors, higher energy storage system) [9]. Despite the extraordinary attributes, safety, short driving range, heavy 
weight, long recharge time, and high initial cost present a great challenge which hinders the widespread EVs in the global market.

Since the burst of the global EVs sales, there have been frequent reports concerning dreadful fire incidents, which are mostly linked with the ignition of Li-ion battery [10,14-17]. Some of the fire incidents were emerged as frightful and some led into demises of EV occupants. For instance, fire incidents involving Tesla Model S in West Hollywood [18], California [19], Zurich [20], Florida [21,22], Indianapolis [23], Tesla Model X in Mountain View-CA [24], Amsterdam [25], and BYD e6 in Shenzhen [26]. More statistics regarding the EV fire accidents have been documented by the specific official agencies in respective countries. For example, China, the global leader in EV sales by volume, recorded an annual average of 31 fire incidents with $36.9 \%$ and $26.2 \%$ of incidents dominated by sudden ignition and charging, respectively [17]. In the U.S.A., 17 Tesla fire incidents out of 350,000 incidents and 3 BMW i3 fire incidents out of 175,000 were recorded [17]. Notably, most of the incidents are characterized by huge impact at high speeds, large fires caused by energetic and combustible Li-ion battery components that are difficult to extinguish. Although statistically EV fire incidents may occur rarely, the fires of Li-ion battery pose safety concern such as intense heat release, diverse species of toxic gases noxious smoke, and risk of fire. In comparison to conventional vehicles, EVs are seen to be safer regarding that battery fires usually take some time to attain the heat essential to trigger the fire, while fossil fuel fires ignite almost immediately when they come in contact with a spark, and blowouts quickly. In terms of severity, the report from Tesla [27] claimed that for 300,000 models driven in a total of 7.5 billion miles, reported roughly a rate of 40 fires per billion miles traveled compared to 55 fires per billion miles traveled in gasoline cars. In 2019 the London Fire Brigade reported 54 EV fires compared to 1898 petrol and diesel fires, and in 2020, just $27 \mathrm{EV}$ fires compared to 1021 from petrol and diesel fires [28]. Moreover, the EV fire is limited to the area where the battery pack is enclosed, while in liquid fueled cars the fuel spills which demand more effort for firefighters to extinguish. Therefore, to further reduce the risk of fire incident and increase protection of occupants during the incident, the safety of EV can always be improved, similar to the occupant safety, before its application.

Various regulations including United Nations Economic Commission for Europe (UNECE) R94, R95, Federal Motor Vehicle Safety Standard (FMVSS 208), GB 20913-2007 from China, and safety programs, i.e., New Car Assessment Program (NCAP) established in various countries such as Japan NCAP, US NCAP, Latin NCAP, Euro NCAP, and ASEAN NCAP are adopted worldwide to test the safety of EVs. Furthermore, research is conducted to characterize and examine various vehicle behaviors and their implications to the safety of occupants.

This study collects and comprehensively reviews the challenges of crashworthiness of EVs based on the regulations, safety programs, and recent research by comparing them with the real EVs fire incidents found in the literature. Firstly, the concept of crashworthiness and the need for its assessment in EVs are provided. Secondly, the requirements for safety of EVs based on the international standards, national standards, regulations and other laboratories standards, and safety of occupants from the regulations and safety programs are presented. Thirdly, the statistical fire incidents of EVs reported throughout the world, typically in light duty passenger vehicles, are highlighted and distinct scenarios are elucidated. Finally, the crashworthiness conducted based on regulations and research is compared to real-world EV fire incidents, highlighting potential problems, research gaps, and future possibilities. This study seeks to enlighten EV, battery, and fire specialists on important elements of EV development. Such knowledge should significantly accelerate the rate at which viable solutions to the challenges now impeding EV adoption are sought.

\section{The Concept of Crashworthiness of EVs}

The crashworthiness defines the ability of the vehicle structure to sufficiently provide protection in the accident involving persons against body injury and protect its cargo 
against damage during an accident [29]. Apart from safety, crashworthiness has a key contribution toward development of safe, reliable, and comfortable vehicles. EV is designed similarly to conventional vehicle design strategies except that it contains electrified drivetrain which replaces the internal combustion engine in the front compartment, with the addition of battery pack and structural modification to support the additional vehicle weight. As a result, using these new car materials, it is critical to investigate EV crash behavior. The EV structure of consists of the body frame, chassis, drive system, and energy storage system. An example of these main components and their functions toward crashworthiness are shown in Figure 1. For frontal and rear crashes, the body frame forms the crumple zone to absorb the kinetic energy, lower the acceleration, and protect the occupant and other vehicle components. The presence of energy storage system with energetic and flammable materials introduces another safety issue once it deforms due to collision. The deflection of the cells might result in a short circuit within one or more cells, generating heat that could ignite the chemicals within the cell. The resulted flame propagates to the adjoined cells and explode, which in turn could endanger the occupants. Since diverse battery chemistries are already commercialized, their proneness to ignition, huge heat released, and toxicity rise an attention to researchers to further examine the crashworthiness of EVs.
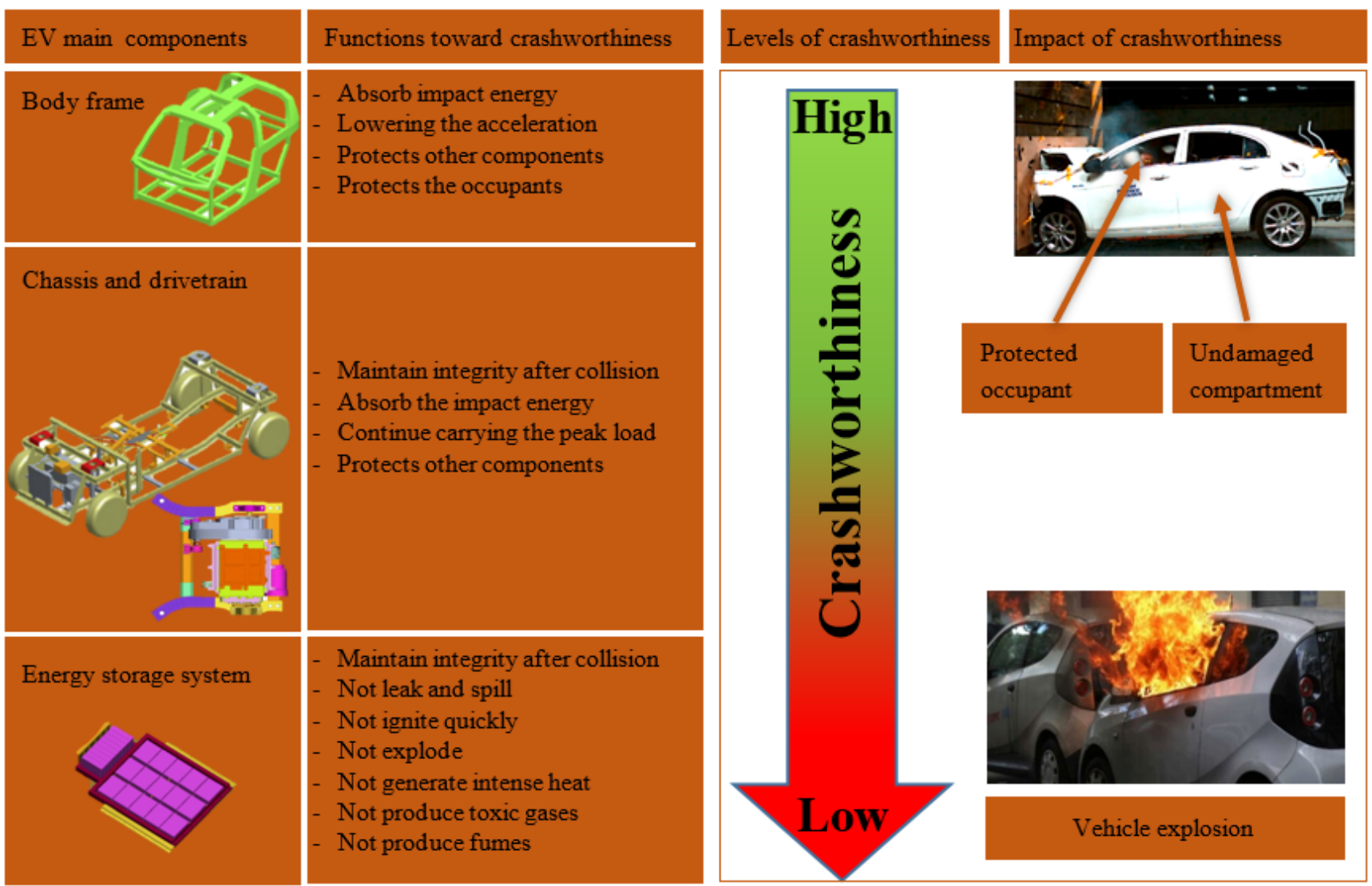

Figure 1. Examples of EV main components, their functions to enhance crashworthiness, and impact of the crashworthiness on EVs. The body frame and chassis are from Liu et al. [30] with permission from Elsevier, the drivetrain and energy storage system are from Navale et al. [29], with permission from Taylor \& Francis. The impacts of the levels of crashworthiness are displayed on the right images as an example. The EV shown on the top right is from Yu et al. [31], with permission from Elsevier, and on the right bottom is from Science Focus [32].

\section{Requirements for the Safety of EVs and Occupants}

3.1. Requirements for the Safety of EVs

EVs must be subjected to the same stringent crash testing and meet a certain safety standards as conventional cars. Moreover, EV-specific standards must also be met ensuring 
the safety of specific components. However, production standards for EV are not applied only to the whole vehicles, but also to the safety of individual components. For example, ensuring protection of energy storage system against crashes, no chemical leakage, and isolating the chassis from the high-voltage to prevent an electric shock. Besides, the crashworthiness of EVs is prone to be affected by their mass and distribution of the center of gravity [33].

Energy storage system is the heart of the EV and its safety may pose risk to the whole vehicle. In the increased awareness on safety of stringent crash regulations, automakers have also started to consider the safety of energy storage system for improved crashworthiness. Li-ion battery (LIB) is widely employed to store the electrical energy used for EV propulsion and it falls into three form factors, namely cylindrical, pouch, and prismatic (see in Figure 2a). The LIB cells are normally stacked together in an appropriate fashion to form a module and later a battery pack in order to produce an intended voltage (Figure $2 b, c)$. Then, the battery pack is configured in either underfloor, T-shaped, or rear configuration to meet the space and performance requirement of the EV. The pack configuration is carefully selected to protect the battery as best as possible in combination with a high quality of occupant protection. Nevertheless, most of the OEMs buy cells and they assemble the cells to modules and a pack. Hence, the safety of LIBs in vehicles is a priority of the manufacturers before installing in the EV.

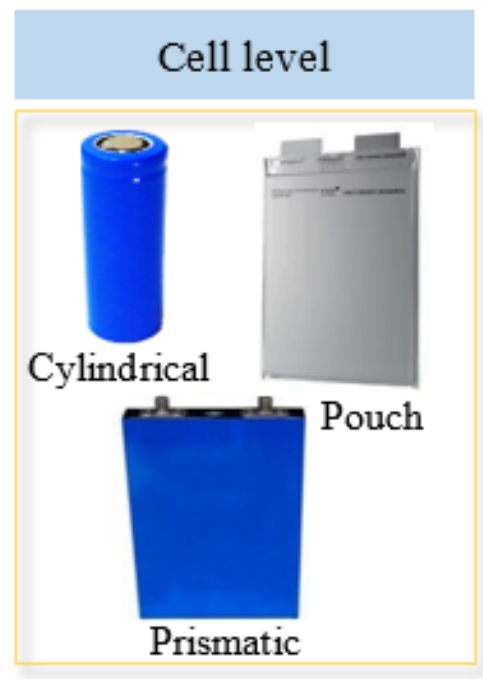

(a)

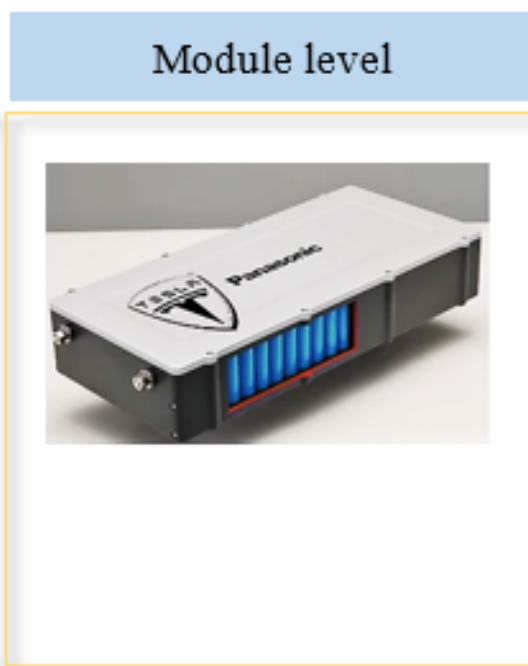

(b)

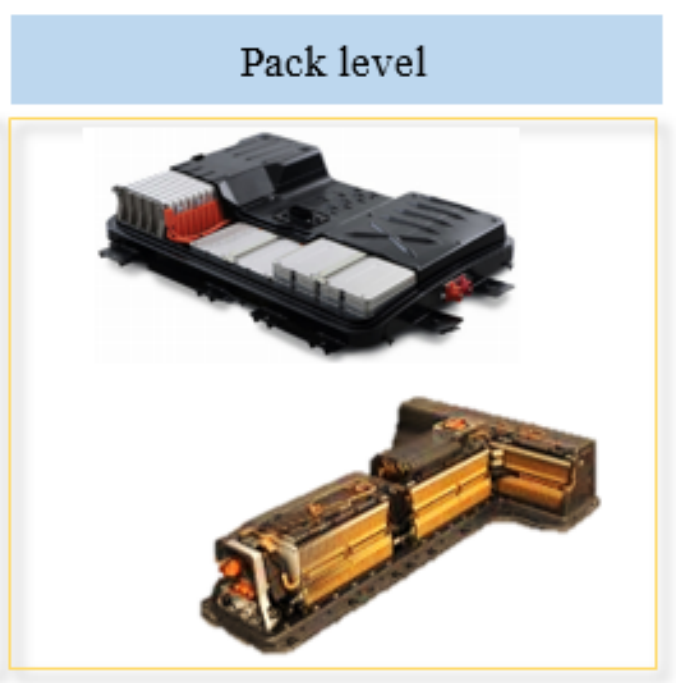

(c)

Figure 2. Types of Li-ion battery used as energy storage system in EVs: (a) Li-ion battery in cell level; (b) module level; and (c) pack level. The photos of pouch cell and module are from Sun et al. [15]. The photos of packs are from Warner [34], with permission from Elsevier.

For successful applications in EVs, LIBs need to be tested and meet the safety requirements. Three abuses such as mechanical, electrical, and thermal abuses are typically used to represent the field phenomena. To characterize the road circumstances, only mechanical abuses on LIBs will be explored. The principle objective of the mechanical abuse is to evaluate and ensure that LIB remains safe in all road circumstances. The level of test varies from cell to pack or vehicle level depending on the standard or regulation. Table 1 shows the list of international standards and regulations employed in mechanical abuse tests, and they are defined as follows:

- $\quad$ Society of Automotive Engineers

$$
\begin{array}{ll}
\bigcirc & \text { SAE J2464 [35] } \\
\bigcirc & \text { SAE J2929 [36] }
\end{array}
$$

- International Organization for Standardization 
ISO 12405-1 [37]

ISO 12405-2 [38]

ISO 12405-3 [39]

- International Electrotechnical Commission

$\begin{array}{ll}\bigcirc & \text { IEC 62660-1 [40] } \\ \bigcirc & \text { IEC 62660-2 [41] } \\ \bigcirc & \text { IEC 62660-3 [42] }\end{array}$

- $\quad$ United Nation (UN)

UN/ECE Regulation No. 100.02 [43]

- Underwriters Laboratories

UL 2580 [44]

- National standards

$\begin{array}{ll}\bigcirc & \text { KMVSS Article18-3 [46] } \\ \bigcirc & \text { AIS-048 [47] } \\ \bigcirc & \text { QC/T 743 [48] } \\ \bigcirc & \text { GB 38031 [49] }\end{array}$

Table 1. List of international standards, regulations, and national standards and their levels of mechanical tests, (from Ruiz et al. [45], with permission from Elsevier).

\begin{tabular}{|c|c|c|c|c|c|c|c|c|c|c|}
\hline \multirow[b]{2}{*}{$\begin{array}{c}\text { Type of } \\
\text { Test }\end{array}$} & \multicolumn{5}{|c|}{ International Standards } & \multirow{2}{*}{$\begin{array}{c}\text { EU } \\
\text { UN/ECER } \\
\text { 100.02:2013 }\end{array}$} & \multirow{2}{*}{$\begin{array}{c}\text { US } \\
\text { UL } \\
2580: 2013\end{array}$} & \multirow{2}{*}{$\begin{array}{c}\text { Korea } \\
\text { KMVSS } \\
\text { 18-3:2009 }\end{array}$} & \multirow{2}{*}{$\begin{array}{c}\text { India } \\
\text { AIS-048: } \\
2009\end{array}$} & \multirow{2}{*}{$\begin{array}{c}\text { China } \\
\begin{array}{c}\text { QC/T } \\
\text { 743:2006 }\end{array}\end{array}$} \\
\hline & $\begin{array}{c}\text { SAE } \\
\text { J2464:2009 }\end{array}$ & $\begin{array}{c}\text { SAE } \\
\text { J2929:2013 }\end{array}$ & $\begin{array}{c}\text { ISO } \\
12405- \\
1(2): 2012\end{array}$ & $\begin{array}{c}\text { ISO } \\
12405- \\
3: 2014\end{array}$ & $\begin{array}{c}\text { IEC } \\
62660- \\
2(3): 2011\end{array}$ & & & & & \\
\hline $\begin{array}{l}\text { Mechanical } \\
\text { shock }\end{array}$ & C M P & C M P V & $\mathrm{P}$ & $\mathrm{P}$ & $\mathrm{C}$ & C M P V & C M P & & M & \\
\hline Drop & $\mathrm{P}$ & $\mathrm{P}$ & & & & & $\mathrm{CP}$ & $\mathrm{P}$ & & \\
\hline Penetration & C M P & & & & & & & & & $\mathrm{C}$ \\
\hline Immersion & MP & $\mathrm{P}$ & & $\mathrm{P}$ & & & M P & $\mathrm{P}$ & $\mathrm{CM}$ & C P \\
\hline Crash/crush & C M P & $\mathrm{PV}$ & & P V & $\mathrm{C}$ & C M P V & C M P & & & $\mathrm{CP}$ \\
\hline Rollover & $\mathrm{P}$ & $\mathrm{P}$ & & & & & $\mathrm{P}$ & & M & \\
\hline Vibration & & C M P & $\mathrm{P}$ & $\mathrm{P}$ & $\mathrm{C}$ & CMP & C M P & & M & $\mathrm{P}$ \\
\hline
\end{tabular}

The letter C, M, P, and V representing cell, module, pack, and vehicle levels. More details regarding the standards for performing mechanical abuse tests are found in [45]. During abusing, the battery may develop different levels of hazards depending on the type of abuse, chemistry and internal passive protection devices. It would be worthy to say that the basic requirement is that the LIB does not ignite or explode for a defined time. For instance, "no fire", "no explosion", "no rupture", and "no leakage" are set as pass criteria for UN/ECE-R100.02, ISO 12405-3, and UL 2580 standards [45]. The European Council for Automotive R\&D (EUCAR) defined different levels of hazards from the abused Li-ion battery and set categories for passed and failed battery, as shown in Table 2. All of the green and yellow colors represent a lower level of hazard, while the red colors represent a high level of hazard.

The battery pack of LIB is normally fixed on the frame together with other infrastructure including module cases, wiring and battery management system to protect the battery pack from external shocks, heat, and vibration. With the advanced design of LIBs, battery pack, and vehicle structures, most of the EV collisions are not expected to cause destruction to the battery pack [16]. The common approach employed by automakers is to place the LIB packs into the reinforced areas of the vehicle (Figure 3a), farther away from front and rear impact absorbing zones [7] (Figure 3b), aiming to reduce the risk of penetration during the accidents. 
Table 2. EUCAR hazard level for the tested Li-ion battery (from Brandt, Garche [50], with permission from Elsevier).

\begin{tabular}{|c|c|c|c|c|c|c|c|c|}
\hline \multirow{2}{*}{ Effect } & \multicolumn{8}{|c|}{ Hazard Level } \\
\hline & $\mathbf{0}$ & 1 & 2 & 3 & 4 & 5 & 6 & 7 \\
\hline $\begin{array}{c}\text { No effect } \\
\text {-no loss of functionality }\end{array}$ & & & & & & & & \\
\hline Loss of functionality & & & & & & & & \\
\hline $\begin{array}{l}\text { Passive protection activated } \\
\text {-cell reversible damaged }\end{array}$ & & & & & & & & \\
\hline $\begin{array}{c}\text { Damaged } \\
\text {-cell irreversible damaged }\end{array}$ & & & & & & & & \\
\hline $\begin{array}{c}\text { Leakage } \\
\text {-electrolyte loss } \leq 50 \%\end{array}$ & & & & & & & & \\
\hline $\begin{array}{c}\text { Leakage } \\
\text {-electrolyte loss }>50 \%\end{array}$ & & & & & & & & \\
\hline Venting & & & & & & & & \\
\hline Fire or flame & & & & & & & & \\
\hline Rupture & & & & & & & & \\
\hline Projectile & & & & & & & & \\
\hline Active mass ejections & & & & & & & & \\
\hline Explosion & & & & & & & & \\
\hline Disintegration & & & & & & & & \\
\hline
\end{tabular}

(a)

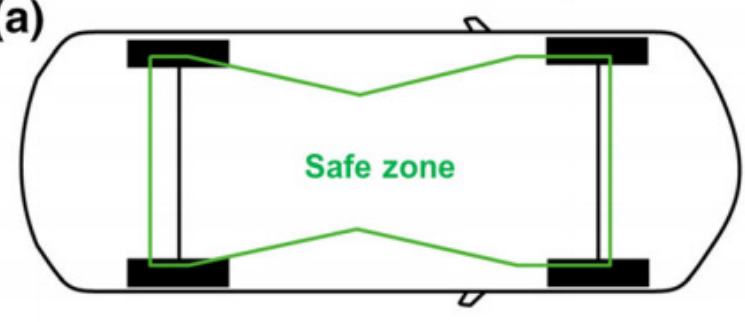

(b)

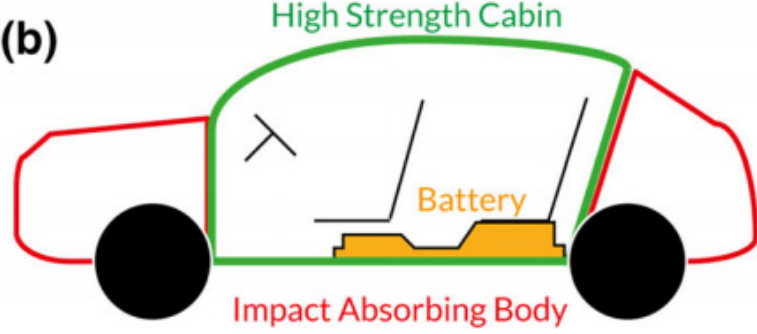

Figure 3. Protection of the battery pack in EVs: (a) Safe zone for battery pack; (b) impact absorbing zone for reducing the risk of penetration during the crash accidents [15].

\subsection{Requirements for the Safety of Occupants}

The safety of the EV occupant after crash can be foreseen in terms of: electrical safety, against mechanical deformation of the vehicle structure, and spillage of the hazardous chemicals. The electrical safety aims to ensure prevention of an electric shock to the occupant during or after the crash. The concept of electrical safety relies on providing protection against direct and indirect contact with high-voltage components.

For the case of occupant protection against vehicle structure, deformation pressure on EV makers is exercised through advanced safety programs, termed as New Car Assessment Program (NCAP). The NCAPs and other regulations consider to test the vehicle as a whole [5]. A series of crash tests are usually performed to mimic the most common road incidents such as frontal impact, side impact, and rear-end crashes. In all crash tests, dummies are employed to quantify the forces and possible injuries a driver may incur after a crash. The data collected from the dummy (triggered by the motion of the dummy during the crash) are evaluated, together with an inspection of vehicle deformation, other on-board safety systems, and scores are given for each specific crash test. The criteria for performing assessments are based on the injury criteria. In this section, a comparison of injury criteria based on the NCAPs from the United States, Europe, Latin America, Japan, China, and ASEAN countries are highlighted. Additionally, UNECE Regulations and Chinese standards are added to provide a critique comparison. The regulations and safety programs are defined below. 
- $\quad$ Euro NCAP [51]

- US NCAP [52]

- Latin NCAP [53]

- JNCAP [54]

- ASEAN NCAP [55]

- CNCAP [56]

- UN/ECE Regulation No. 94 [57]

- UN/ECE Regulation No. 95 [58]

- GB 11551 [59]

- GB20071[60]

- FMVSS 208 [61]

- FMVSS 214 [62]

- FMVSS 301 [63]

The crash test intends to examine the injury to the head, neck, chest, and legs of the driver and right fore-passenger. The details of the employed regulations for the safety requirements for occupants during frontal, side, and rear tests are found in $[55,59,64,65]$. In the safety requirements for occupants during full-wrap frontal, side, and rear collision test, speed is mostly considered for comparison with recent research and real-world fire incidents.

\section{Recent Research on Crashworthiness of EVs}

This chapter focuses on the crashworthiness of the EV in vehicle level. In several years researchers have been analyzing the ability of vehicles to protect the safety of occupant during the accident. This has been done by (a) performing real crash tests through the use of vehicle prototype, (b) simulating the vehicle crash on computer software by considering vehicle parameters obtained from the experiment. The tests are complex experiments with large non-linear deformations involving multiple iterations of design, prototype, and crash tests. In general, to perform a vehicle crash requires enough man-hours, although it produces accurate results. Moreover, real crash experiments need expert persons, sophisticated environment, prototype vehicle for crashing, sensing, and measuring system, etc.

O'Malley et al. [33] reported crash tests performed by Insurance Institute for Highway Safety (IIHS) and Australasian New Car Assessment Program (ANCAP) to analyze the safety of occupants and vehicle dynamics in frontal collision under moderate overlap $40 \%$ offset into deformable barrier at $64 \mathrm{~km} / \mathrm{h}$ and small overlap $25 \%$ offset into rigid barrier at $64 \mathrm{~km} / \mathrm{h}$. The report of IIHS showed that the area around the vehicle's battery pack remained undamaged in all test scenarios with no electrical problem. Palvoelgyi and Stangl [66] crashed an electric G-van at $48 \mathrm{~km} / \mathrm{h}$ and results showed the detachment of battery tray from the vehicle and uncontrolled g-loadings to the car. Uwai et al. [7] tested a newly developed body structure of Nissan to evaluate the protection of occupants against direct contact and deformation of the battery pack. The vehicle with the new body and battery pack were tested in the frontal test at $64 \mathrm{~km} / \mathrm{h}$ with a deformable barrier, $32 \mathrm{~km} / \mathrm{h}$ side pole test, and $80 \mathrm{~km} / \mathrm{h}$ rear test. The impact sensing system was installed to shut down the high voltage during the crash, while fuses were used to protect electric shock and short circuits. After all tests, neither battery pack deformation nor electrical conduction was observed. EVERSAFE project [67] investigated the characteristics of high-voltage system during/after the collision test, identified signs for discovery of hazards, and examined the current post-crash harmless handling procedures. To do so, a side impact test with a movable pole impactor was performed on the Mitsubishi i-MiEV equivalent to Euro NCAP side pole test, and examined electrical, mechanical, thermal, and chemical parameters. The test resulted into no obvious damage to the battery pack and the high-voltage outside the battery pack dropped below $60 \mathrm{~V}$ as required by vehicle safety regulations. Moreover, autopsy revealed no indications of electrical, thermal, or chemical hazards to occupants' compartment. With the same objectives, BMW i3 was impacted at the rear by a crash trolley. In the observations, only mechanical damages were noticeable. The cabin had no intrusion 
but the passenger doors were opening easily. Unfortunately, the dummy driver was not set, hence, no injury assessment was done.

The small overlap test has been executed to mimic the road crash when the driver has failed to avoid the collision completely. The goal of the test is to assess the strength and energy dissipation ability of the cabin from the outer edges of the vehicle. However, the minimal energy absorbing strength of the exposed structure compromises the safety of the occupant.

The current common small overlap tests are $25 \%$ and $40 \%$ frontal offset tests. The $25 \%$ small overlap test performed by Polestar [68] reported the following observations: quick detachment of the front wheel which increases the chance for structural stack-up and deformations into the cabin, serious damage on the Severe Partial Offset Crash (SPOC) block (a metal bracket on each side of the chassis that protects metal intrusions during the impact), and unscathed battery pack.

Crashes between vehicles and round poles are common both inside and outside the urban areas. Normally, this kind of crash occurs in populated areas where many utility poles are installed, mainly along the roads, or on roads where signs or traffic lights are fixed. Out of urban areas, this kind of crash occurs often with the trees or utility poles located along the roads. It is also among the crashes that contribute significantly to dweller fatalities and serious harms [69]. Front pole test is common in conventional vehicles, see previous tests in $[69,70]$. Unfortunately, neither NCAPs nor IIHS executes front pole test in EVs. In doing the test, the vehicle crashes a rigid round pole at the center of the frontal width while missing both side members for absorbing the impact energy. Due to the absence of structure elements in the middle of the frontal width to stop the vehicle and absorb the impact energy, the intrusion rate is elevated in this test and emerges as a tough test for automakers and designers.

In general, performing real-world crashworthiness is an expensive and time-consuming task [71]; additionally, very few experimental data are publicly available. Luckily, the availability of high computing machines and crash simulation software with parallel computing techniques has revolutionized the crash tests. The useful experimental parameters have been adopted to generate simplified numerical models, which are employed to characterize different vehicle designs. For these reasons, various models have been employed to predict the vehicle behavior and reduce the necessity of full-scale impact test. These approaches include lumped parameters models (LPMs), beam element models (BEMs), and finite elements models (FEMs). All approaches originate from the principles of structural mechanics that fulfils the conservation of mass, energy and momentum. However, the selection of a particular approach vary widely depending on the required simplicity.

Syuhri [72] designed the optimal bumper in a racing EV using shock absorber to dissipate the impact energy during the frontal collision. First, derivation of the mathematical model and LPM was performed to obtain the dynamic behavior of structure occurred in the frontal crash. Second, the hydraulic crash damper was incorporated in the mathematical model and then numerical simulation was applied to obtain optimal value for the hydraulic crash damper. Finally, a comparison was made between the initial model and the new model with an optimal crash pulse. When crashed at a speed from $20 \mathrm{~km} / \mathrm{h}$ to 100 $\mathrm{km} / \mathrm{h}$, the percentage energy absorbed was in the range of $88.03 \%$ to $64.7 \%$. Moreover, the developed model showed a better response and has the ability to dissipate $72.9 \%$ crash energy than the initial one when crashed at $65 \mathrm{~km} / \mathrm{h}$. The new model was able to reduce vehicle deceleration, occupant deceleration, and vehicle deformation in the range of $25 \%$ to $28.1 \%$ compared to the initial model [72].

Despite the useful results in terms of vehicle designs and crash evaluation, many challenges of LPM have been reported in literature. For instance, Munyazikwiye et al. [71] reported that the main drawback of LPM is its reliance on the readiness of calibration data prior to undertaking the crash analysis. Meaning that, the spring characteristics of the LPM model need to be obtained either from a full-scale impact test or from FEM model [46]. In 
addition to that, the validity of the LPMs for the similar data of their adopted models and same test speeds are the big challenges that opens the room for further research [71].

In recent years, the explicit non-linear finite element analysis (FEA) has emerged as, undoubtedly, the most widely renowned modelling approach in EV crashworthiness due to its high accuracy in material specifications, stresses, and deformation during the impact [73]. The aspects of analyses include the structural behavior of the vehicle and mechanisms for protecting against high-voltage. Belingardi and Obradovic [74] developed an FEM impact attenuator crash to absorb the kinetic energy during the frontal impact of an EV Formula student car body. The improved structure showed an average deceleration of about $14 \mathrm{~g}$, which is in good standing with the requirements of the SAE 2008 rules, a value lower than $20 \mathrm{~g}$ along the Y-axis. Arifin and Gunawan [75], using Abaqus software, presented the design and testing of impact attenuator on the Formula SAE FG17 Garuda UNY. The average deceleration of $15.908 \mathrm{~g}$ was achieved by the impact attenuator and met the 2017 Formula SAE regulation. Zhang, Zhou, and Xia [76] developed an FEM simulation model of the small lightweight EV (SLEV) to examine the effects of the front wheels on the crash load transfer and load path, intending to quantify the crash energy absorbed due to tire deformation.

The SLEV model underwent a full-wrap frontal test with rigid barrier, $40 \%$ offset frontal test with deformable barrier, and small overlap test with rigid barrier. In general, the front tires absorbed a significant portion of kinetic energy that is comparable to that of other front structural members. Some examples of FEM models developed by researchers to evaluate the crashworthiness are shown in Figure 4.

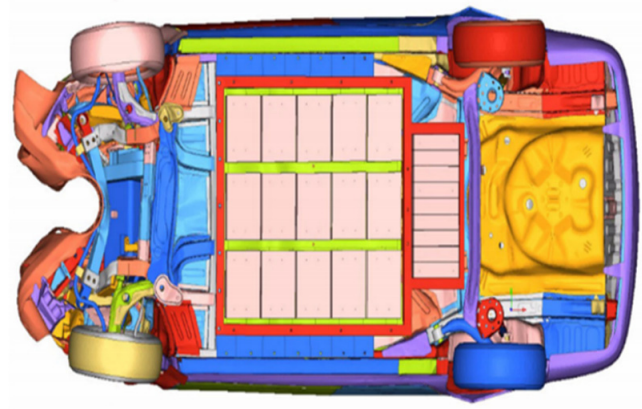

(a)

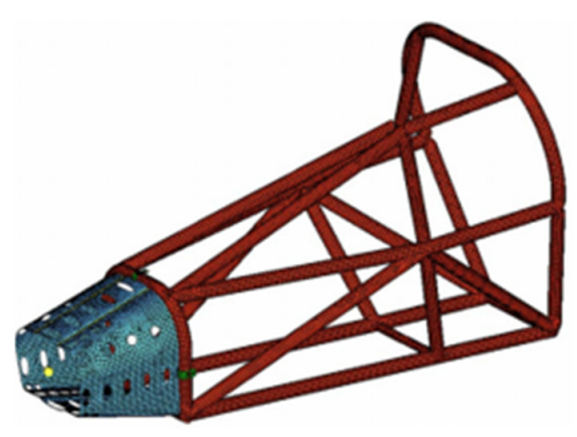

(c)

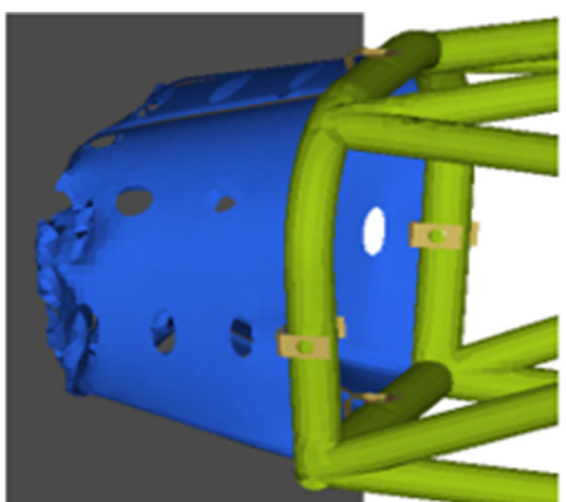

(d)
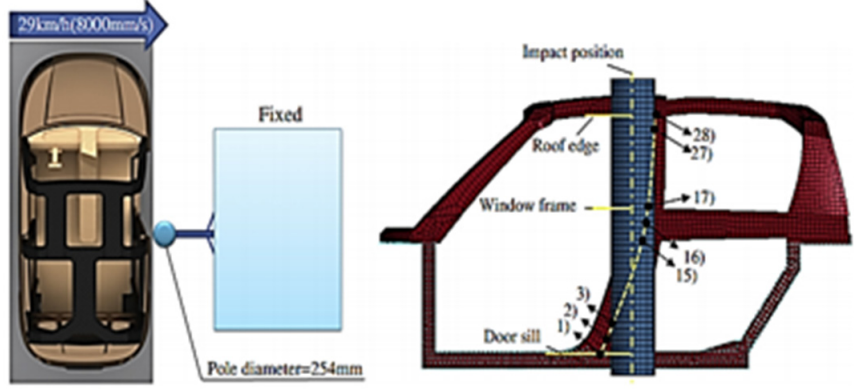

(b)

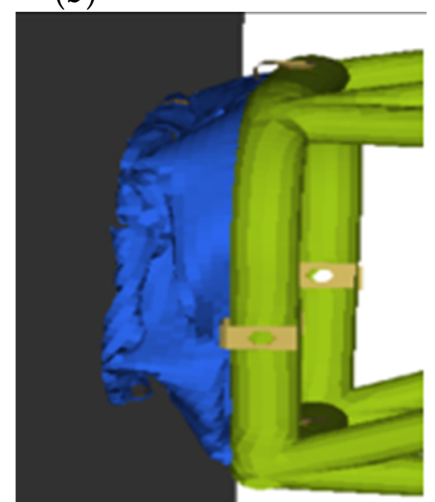

(e)

Figure 4. Examples of FEM models developed to evaluate the crashing behavior of vehicles: (a) the frontal pole test undertaken at $50 \mathrm{~km} / \mathrm{h}$ on a rigid pole [From Navale et al. [29], with permission from Taylor \& Francis]; (b) the side pole impact test undertaken at $29 \mathrm{~km} / \mathrm{h}$ in LS-DYNA [From Liu et al. [30], with permission from Elsevier]; (c) the meshed impact attenuator on Hyper View; (d) $14 \mathrm{~ms}$ after crashed at $25.2 \mathrm{~km} / \mathrm{h}$; (e) at the end of crashing event [From Belingardi and Obradovic [74], with permission from Serbian Society for Computational Mechanics]. 
Roland et al. [77] used LSDYNA explicit FE code to analyze a detailed model of a battery pack, and mimic its response under EuroNCAP side pole test with a test speed of $29 \mathrm{~km} / \mathrm{h}$ into a rigid pole. Moreover, their crashworthiness results showed that hexagonal pack is superior in occupancy rate and energy absorption characteristics compared with trapezoidal and rectangular packs. Li et al. [78] performed a full frontal crash test using a Chinese regulation (GB11551-2014) on the FEM model to explore the lightweight design and crashworthiness of EV. The numerical results of Chen, Cheng, and Kun [79] showed that the composite materials are beneficial for putting on to the energy-absorption elements. Schäffer et al. [80] performed a study on door sill structure through a multi-level optimization to secure the battery pack floor during side pole crash. Better energy absorption from the improved door structure showed enhanced security to the battery pack. The developed model was validated against Euro NCAP test at $29 \mathrm{~km} / \mathrm{h}$. The work in [81] optimized the flexible structure of the battery pack to enhance the crashworthiness of EVs during the head-on collision. Results found a significant reduction on occupant compartment acceleration when using battery packs as energy-absorption components. Setiawan and Salim [82] presented FEM model to examine the performance of energy absorbing materials for securing the battery pack against the oblique side pole crash at $32 \mathrm{~km} / \mathrm{h}$. The use of aluminum foam as a filler for the door sill structure, showed an adequate battery pack deformation of $9.4 \mathrm{~mm}$ compared to the $15.3 \mathrm{~mm}$ limit.

Zhang et al. [83], using LS-DYNA software, presented FEM simulation results of a converted EV by examining the layout of the battery pack followed by topology optimization. The full-wrap frontal and side impacts were used to evaluate the modified EV. The results efficiently showed crashworthiness modified EV, while dropping the weight. Sakurai and Suzuki [59] observed that the used conventional car, when transformed to EV, may have poor distribution of mass affecting the center of gravity.

To sum up, despite the challenge of long-time usage in vehicle modeling, yet FEM remains the most popular software for EV crashworthiness in the recent studies. The dynamics of the EV deformation have been critical for analyzing the safety of occupants and battery pack. Improving the front end structure of EV and usage of energy absorbing components can enhance the protection of the occupant, whereas the lightweight design and composite materials can secure the damage on the battery pack floor. However, most of the simulations are not considering the electrocution and chemical spillage and their hazard. In EV battery, the chemicals pose the danger of fire ignition while electrocution endangers the occupant, hence, they need to be considered in the future research.

\section{Real-World EVs' Fire Incidents}

In this section, some of the publicly reported EVs' fire incidents that occurred on roads are summarized. To cut short, only the fire incidents that took the form of mechanical abuses have been considered. The accidents were grouped according to their type of mechanical abuses such as penetration, crash, drop, rollover, and immersion and are listed in Table 3.

Table 3. Real-world EVs' fire incidents in the form of mechanical abuses.

\begin{tabular}{cc}
\hline Type of Mechanical Abuse & Descriptions \\
\hline Penetration & $\begin{array}{c}\text { Tesla Model S caught fire after colliding with a huge piece of metal debris, which destroyed } \\
\text { one of the battery modules. The driver was unharmed. The event occurred close to Seattle }\end{array}$ \\
\cline { 2 - 2 } & $\begin{array}{c}\text { Tesla Model S went over a tow hitch, which damaged the vehicle's undercarriage and caused } \\
\text { an electrical fire; the driver was not harmed. The event took place in Tennessee. }\end{array}$ \\
[85] & $\begin{array}{c}\text { Tesla Model S jumped over a cliff, collided with two boulders at the canyon's bottom, broke } \\
\text { into pieces, and exploded, killing the driver. It happened on Malibu Canyon Road. }\end{array}$ \\
\hline [19]
\end{tabular}


Table 3. Real-world EVs' fire incidents in the form of mechanical abuses.

Tesla Model S was driven at $177 \mathrm{~km} / \mathrm{h}$ through a roundabout when it crashed with a concrete barrier on the left wheel, then the right wheel, and finally a tree.

Tesla Model S impacted into several vehicles and torn apart in half after hitting a light pole in

West Hollywood, ignited and seriously injured the driver and two officers, half of the car stuck in a synagogue

Tesla Model S collided with a tree at high speed, bounced around, and then exploded, killing

$$
\text { the driver and passenger in Indianapolis. }
$$

Tesla Model S went off the road, crashed with a house, and set fire to a garage. The motorist was taken to the hospital in Lake Forest, California, with non-life threatening injuries. The fire was put out by a significant amount of water.

Tesla Model S car exploded instantaneously after hitting with a road barrier in Austria. The driver survived the accident

Tesla Model X traveling at $120 \mathrm{~km} / \mathrm{h}$ collided with two other vehicles, ignited instantaneously, and killed the driver. The accident happened near Mountain View, California.

Tesla Model $\mathrm{S}$ drove off the road at $185 \mathrm{~km} / \mathrm{h}$, collided with a concrete wall, caught fire, and killed two teens while wounding another near Fort Lauderdale, Florida. There were

\begin{tabular}{|c|c|}
\hline $\begin{array}{l}\text { Tesla Model S hit a big vehicle at } 97 \mathrm{~km} / \mathrm{h} \text { in Utah, South Jordan, USA. The frontal damage } \\
\text { was severe, but there was no post-crash fire. }\end{array}$ & [91] \\
\hline $\begin{array}{l}\text { BYD e6 hit from behind at } 180 \mathrm{~km} / \mathrm{h} \text {, crashed with a tree, pierced } 1 \mathrm{~m} \text {, erupted into flames, and } \\
\text { killed three people in Shenzhen, China. }\end{array}$ & [92] \\
\hline $\begin{array}{l}\text { In Guangzhou, China, a Tesla Model X slammed into the center fence at } 76 \mathrm{~km} / \mathrm{h} \text { and was } \\
\text { promptly rear-ended by a Ford vehicle at } 71 \mathrm{~km} / \mathrm{h} \text {, the air bag and rear door failed to deploy, } \\
\text { and passengers were evacuated by the front doors from the backseat }\end{array}$ & [93] \\
\hline Fire broke out from an EV two hours after being hit by a train near Østfold, Norway & [92] \\
\hline $\begin{array}{l}\text { In Moscow, a Tesla Model S collided with a tow truck on a highway, causing a fire. Three } \\
\text { occupants sustained significant post-crash injuries. }\end{array}$ & [94] \\
\hline After colliding with a barrier in Taoyuan City, a Tesla Model 3 caught fire and killed the driver. & [95] \\
\hline $\begin{array}{l}\text { At } 160 \mathrm{~km} / \mathrm{h} \text {, Tesla Model S collided with a Honda carrying five passengers, striking a light } \\
\text { post and severing the car in half. The automobile collided with numerous more vehicles before } \\
\text { coming to a stop near West Holly-wood }\end{array}$ & [96] \\
\hline Tesla Model S slammed into a palm tree and caught fire in Davie, Florida. & [97] \\
\hline $\begin{array}{l}\text { The } 2020 \text { Tesla Model X SUV collided with a } 2017 \text { Subaru Legacy car on Lake Zurich Road near } \\
\text { Barring-ton, injuring all drivers and quickly catching fire }\end{array}$ & [98] \\
\hline $\begin{array}{l}\text { Tesla Model S crashed through a barrier, collided with a tree, and exploded. The driver was } \\
\text { unharmed. To put out the fire, } 12 \text { tons of water were utilized }\end{array}$ & [99] \\
\hline In Connecticut, Tesla Model 3 rear-ended a police cruiser. No one was hurt. & [100] \\
\hline $\begin{array}{l}\text { Tesla Model X veered off the road and crashed with two trees on Fremont's Thornton Avenue. } \\
\text { The driver suffered just minor injuries. The fire was put out using } 13 \text { tons of water. }\end{array}$ & {$[101,102]$} \\
\hline $\begin{array}{l}\text { When attempting to park, Tesla Model } \mathrm{X} \text { abruptly accelerated, colliding with a parked Toyota } \\
\text { Tacoma and swiping the side. }\end{array}$ & [103] \\
\hline $\begin{array}{l}\text { On the highway near Beijing, Tesla Model S rear-ended the Volkswagen Santana's } \\
\text { right-rear bumper. }\end{array}$ & [104] \\
\hline $\begin{array}{l}\text { Tesla Model S collided with the bus at a low speed after hitting the light post with its front edge } \\
\text { and then its right side at high speed. Nobody was hurt. The battery pack was not harmed. }\end{array}$ & [105] \\
\hline In Taiwan, a Tesla Model 3 collided with a vehicle while traveling at highway speeds. & [106] \\
\hline $\begin{array}{l}\text { The white car slammed into the side of the Tesla Model X at great speed. The white car } \\
\text { slammed into the side of the Model X at great speed. }\end{array}$ & [107] \\
\hline $\begin{array}{l}\text { Tesla Model S hit the road sign post, the steel fence, and the tree. Nobody was hurt. The } \\
\text { battery pack was not harmed. It happened in Guangdong Province. }\end{array}$ & [108] \\
\hline
\end{tabular}
two re-ignitions. 
Table 3. Real-world EVs' fire incidents in the form of mechanical abuses.

\begin{tabular}{|c|c|c|}
\hline Type of Mechanical Abuse & Descriptions & Ref. \\
\hline & $\begin{array}{c}\text { The Nissan LEAF collided with another car. The driver was unharmed. There was } \\
\text { no blaze ignited. }\end{array}$ & [109] \\
\hline & $\begin{array}{c}\text { Tesla Model } 3 \text { was traveling at } 80 \mathrm{~km} / \mathrm{h} \text { when a crossing truck lost its tire, causing it to collide } \\
\text { with the Model } 3 \text { at a combined speed of } 160 \mathrm{~km} / \mathrm{h} \text {. The driver was unharmed. There is no } \\
\text { harm to the battery. }\end{array}$ & {$[110]$} \\
\hline & $\begin{array}{c}\text { In Seattle, Washington, a Tesla Model } 3 \text { was rear-ended by another car on the freeway. Neither } \\
\text { a fire nor a major injury happened. }\end{array}$ & [111] \\
\hline & A Volvo Big Rig rear-ended a Tesla Model S, sparking a fire. The driver was unharmed. & {$[112]$} \\
\hline & In Baltimore-Washington, a Tesla Model 3 was rear-ended by a Honda Civic. & [113] \\
\hline & The Tesla Model S collided with another car on a highway in Arizona, U.S. & {$[114]$} \\
\hline & In Malibu, a Tesla Model 3 was rear-ended by a Ferrari. & [115] \\
\hline & The Tesla Model S was hit on the side by a conventional car in Contern, Luxembourg. & [115] \\
\hline & Tesla Model X was struck by a crashed aircraft in Sugar Land, Texas. & [116] \\
\hline & In Oregon, a Tesla Model X collided with a Toyota RAV4 and broke a light pole. & [117] \\
\hline & Tesla Model X collided with a Ford Transit van in Yiwu, Zhejiang Province. & {$[118]$} \\
\hline & $\begin{array}{l}\text { In Laguna Beach, California, Tesla Model S collided with a stopped } \\
\text { police cruiser. }\end{array}$ & {$[118]$} \\
\hline & $\begin{array}{l}\text { In Broward County, Florida, a Nissan GTR traveling at } 137 \mathrm{~km} / \mathrm{h} \text { smashed a Tesla Model } \\
\text { X in half }\end{array}$ & {$[119,120]$} \\
\hline & $\begin{array}{c}\text { Tesla Model 3's right wheel collided with the barrier at } 120 \mathrm{~km} / \mathrm{h} \text {, causing significant damage. } \\
\text { There were no injuries or fires. The scene was in Northern Greece. }\end{array}$ & {$[121]$} \\
\hline & $\begin{array}{l}\text { In Karlsruhe, Germany, a stopped Tesla Model S was struck on one side by a } 7.5 \text { ton truck } \\
\text { traveling at } 60 \mathrm{~km} / \mathrm{h} \text { and collided with a traffic signal post. There was no fire, but the resident } \\
\text { received minor injuries. }\end{array}$ & {$[122]$} \\
\hline & $\begin{array}{l}\text { Tesla Model S was involved in a head-on accident followed by a side impact in the Vallvidrera } \\
\text { tunnels in Barcelona, Spain, when it was hit by the failing station wagon. }\end{array}$ & {$[123]$} \\
\hline & In Amsterdam, a Tesla Model S collided with a tree and caught fire. & [25] \\
\hline \multirow{3}{*}{ Immersion } & \multirow{2}{*}{$\begin{array}{c}\text { Hurricane Sandy caused a fire in Toyota Prius and Fisker Karma submerged in seawater in } \\
\text { New Jersey, USA }\end{array}$} & [92] \\
\hline & & {$[92]$} \\
\hline & $\begin{array}{c}\text { Hundreds of new Maserati automobiles caught fire as saltwater surged and inundated the port } \\
\text { late at night, causing the salt water to ignite the fire in the car batteries and spread to } \\
\text { other vehicles. }\end{array}$ & {$[124]$} \\
\hline \multirow{4}{*}{ Rollover } & $\begin{array}{l}\text { The Tesla Model S collided with a barrier on a central reserve on a highway in Ticino, } \\
\text { Switzerland, flipped over, and burst into flames. The driver was killed in the collision. }\end{array}$ & {$[125]$} \\
\hline & $\begin{array}{l}\text { In Pennsylvania, a Tesla SUV collided with a guard rail, then a concrete wall before rolling } \\
\text { onto its roof. The driver was hurt in the collision. }\end{array}$ & {$[102]$} \\
\hline & In Shanghai, a Model 3 crashed and overturned, but the occupant survived & {$[126]$} \\
\hline & $\begin{array}{l}\text { Tesla Model } 3 \text { crashed with the car and rolled in the air several times before landing upside } \\
\text { down at } 113 \mathrm{~km} / \mathrm{h} .\end{array}$ & {$[127]$} \\
\hline
\end{tabular}

From the publicly reported incidents, different phenomena can be indicated. For instance, in the first two incidents in Table 3 the bottom of the battery modules were hit, caused electrical short circuit, and explosion consequently (see example of explosion in [84]). However, the first case was the large metallic debris, while the second was the three steel ball tow hitch, which may have different dimensions and material specifications. Moreover, the Teslas' battery packs were in motion when they underwent those hits. Thanks to the Tesla for improving the undercarriage of the Teslas' pack by introducing a three shields titanium body to prevent intrusions. For the case of crash, vehicle speed is the critical factor toward the safety of the vehicle. From the incident displayed on the orange color in Table 3 the reported driving speeds before the crashes are $71 \mathrm{~km} / \mathrm{h}$ and $76 \mathrm{~km} / \mathrm{h}$ in Guangzhou, China, $97 \mathrm{~km} / \mathrm{h}$ in South Jordan, USA, $120 \mathrm{~km} / \mathrm{h}$ in Mountain View, California and Northern Greece, 137 km/h in Broward County, Florida, 160 km/h in West Hollywood, 
$177 \mathrm{~km} / \mathrm{h}$ in Merida, Mexico, and $185 \mathrm{~km} / \mathrm{h}$ in Fort Lauderdale, Florida. Other scenarios occurred in Shenzhen, China and Karlsruhe, Germany, in which EVs were hit by another vehicle which was driven at a speed of $60 \mathrm{~km} / \mathrm{h}$ and $187 \mathrm{~km} / \mathrm{h}$, respectively.

Another observation from Table 3 is the presence of multi-crashes, whereby more than one object is crashed or a vehicle crashes more than one time. Referring to scenarios reported in Table 3, many of them were caused by high driving speeds of EVs. As a consequence of high speeds, an EV can crash into more than one object to get stopped. For instance, to mention a few, in Table 3 , incident no. 3 , the vehicle was driven at $177 \mathrm{~km} / \mathrm{h}$ through a roundabout, collided a concrete wall on the left wheel, later on the right wheel, and finally hit a tree. In incident no. 4 , the vehicle crashed into several vehicles and later struck a light pole; see the split car in [96]. Another vehicle in incident no. 13 was driven at $71 \mathrm{~km} / \mathrm{h}$, collided with the fence, and was rear-ended by another car at $76 \mathrm{~km} / \mathrm{h}$. The speed did not look high but it ended up in blaze, see in [93]. In another scenario, incident no. 22 , the vehicle drifted off the roadway and collided into the two trees. In the next scenario, incident no. 23, while the driver was trying to park, they accidentally accelerated the vehicle and hit the nearby vehicle, swiped the side of a parked one, and crash two small round poles; fortunately, the vehicle was at moderate speed. In incident no. 34, the vehicle first hit the road sign pole, metallic fence, and ended up on the tree. More multi-crashes can be observed from Table 3. In general, out of 54 reported incidents in Table 3, 44 incidents are based on the crash abuse and 11 out of 44 incidents involved multi-crashes. For an EV tested with a single crash per time to undergo multi-crashes per incident, it endangers its safety. The situation gets quite alarming when the occupant is choked by the guardrails penetrated through windshields, see examples in [108]. Another distinctive frontal crash among the others where two vehicles had a head-on collision with each other while they are in motion, see in [98]. A similar crash occurred in [116]. Apart from crash abuses, immersion is a silent enemy where many EVs may be destructed in a short time, see in $[92,128]$.

Different types of barriers have been involved in the above reported incidents such as concrete barriers, guardrails, light poles or road sign poles, trees, vehicles, houses, and a combination of these barriers. Examples of a vehicle colliding with a barrier is reported in [93,98], a concrete block in [88], and a tree in [99]. In the reported multicrashes, 33 incidents were single barrier crashes. In terms of barriers, 8 crash incidents involved trees, 7 crash incidents involved round poles ( 5 incidents in light pole, 1 incident in road sign pole, and 1 incident in traffic light pole), 7 crash incidents involved roadblocks (6 involved concrete barriers and 1 guardrail), 29 incidents involved vehicle crashes (such as rear, frontal, or side impacts), and 1 incident where a vehicle crashed into a house. Another distinct crash is when vehicles crashed their roofs. For example, in incident no. 45 , the vehicle flipped and hit its roof with all its weight, see [126], in incident no. 36 the vehicle's bonnet was hit by the tire which moved at $160 \mathrm{~km} / \mathrm{h}$, and in incident no. 43 the front edge of the vehicle was hit by the crashing plane.

The presence of high temperature and toxic gases can make battery pack's explosion dangerous to EVs' occupants and nearby properties. For example, in incident no. 5 the driver's body was burnt beyond recognition after his vehicle plunged off a cliff. In incident no. 8, as reported in [87], the battery fire was reported to emerge after colliding with the concrete barrier and became enormously severe and produced a lot of poisonous gases. Five firefighting trucks and 35 firefighters were used to put out the fire while copious amounts of water were employed to cool the battery's temperature. Large amounts of water have been also used in incident no. 20 and 22. The burning of house engulfed from the slammed EV has been report in incident no. 7 .

\section{Challenges between Regulations/Safety Programs, Research, and Real EVs' Fire Incidents}

\subsection{Crashing Speed}

From Section 3.2, the test speeds in both regulations and safety programs range between $40 \mathrm{~km} / \mathrm{h}$ and $70 \mathrm{~km} / \mathrm{h}$ in frontal impact tests, $30 \mathrm{~km} / \mathrm{h}$ and $80 \mathrm{~km} / \mathrm{h}$ in rear 
impact tests, and $50 \mathrm{~km} / \mathrm{h}$ and $70 \mathrm{~km} / \mathrm{h}$ in side impact tests. For EV models that pass the safety requirements, a rank is awarded to indicate their levels of safety and protection to occupants. In the recent research, test speeds in both experiments and simulations are in-line with those in regulations or safety programs. For example, EVERSAFE project in [67] adopted some requirements for Euro NCAP side pole test and FMVSS 214 and crashed a Mitsubishi i-MiEV at $35 \mathrm{~km} / \mathrm{h}$, whereas BMW i3 was rear-ended at $80 \mathrm{~km} / \mathrm{h}$ as per FMVSS 214. Likewise, simulation studies have been adopting either regulations or safety programs to perform crashworthiness studies. For example Li et al. [78] adopted a Chinese regulation-GB11551-2014 - to the developed FEM model to simulate a full frontal crash test on a rigid wall at $50 \mathrm{~km} / \mathrm{h}$. Zhang et al. [83] adopted China NCAP (C NCAP) for full wrap frontal crash tests at a speed of $50 \mathrm{~km} / \mathrm{h}$. Euro NCAP side pole tests with a test speed of $29 \mathrm{~km} / \mathrm{h}$ were adopted in FEM models of Roland et al. [77] and Schäffer et al. [80], while Setiawan and Salim [82] simulated an oblique side pole test at $32 \mathrm{~km} / \mathrm{h}$. Regarding the EVs' fire incidents reported in Table 3 and their discussion provided in paragraph 2 of Section 5, the frontal crash speeds are $71 \mathrm{~km} / \mathrm{h}$ (Guangzhou, China), $97 \mathrm{~km} / \mathrm{h}$ (South Jordan, USA), $120 \mathrm{~km} / \mathrm{h}$ (Mountain View, California and Northern Greece), $137 \mathrm{~km} / \mathrm{h}$ (Broward County, Florida), 160 km/h (West Hollywood), 177 km/h (Merida, Mexico), and $185 \mathrm{~km} / \mathrm{h}$ (Fort Lauderdale, Florida). The reported crash speed for side impact was $60 \mathrm{~km} / \mathrm{h}$ and occurred in Karlsruhe, Germany, while for the rear-end crash the speed was $185 \mathrm{~km} / \mathrm{h}$ (Shenzhen, China).

Comparatively, the regulations and safety programs perform the full-wrap frontal tests at speeds ranging between $40 \mathrm{~km} / \mathrm{h}$ and $70 \mathrm{~km} / \mathrm{h}$, which are in-line with recent research, while the real-world fire incidents ranged between $70 \mathrm{~km} / \mathrm{h}$ and $190 \mathrm{~km} / \mathrm{h}$. Consequently, the post-crash damages were reported as extremely severe including demise of occupants, destruction of vehicle, and nearby properties. Since fatal crashes have been aggravated by high speeds, most of EVs in the global market are prone to undergo fatal crashes when driven at high speed. As examples, Porsche Taycan Turbo S [129], Tesla Model S [130], 2019 Nissan LEAF [131], and 2019 Volkswagen e-Golf SE [114] can accelerate from 0 to $100 \mathrm{~km} / \mathrm{h}$ in $2.8 \mathrm{~s}, 3.2 \mathrm{~s}, 7.9 \mathrm{~s}$, and $9.6 \mathrm{~s}$, respectively. Moreover, the serious implications of high-speed crashes include extreme destruction or split of vehicles, burning of nearby properties when explosion occurs, and dreadful demise. Therefore, regarding the fast acceleration and high speeds of EVs, the safest EVs should be the ones fulfilling the injury criteria with the highest margin. However, achieving the high margin needs to take into account the cost of elevated impact energy, modified vehicle structure, and more space for dissipation of impact energy.

\subsection{Multiple Crashes per Incident}

In the recent reported EVs' fire incidents, multi-crashes have been emerged as repetitive and have caused disastrous incidents. As example, 11 out of 53 incidents reported in Table 3 involved multi-crashes. In one way, multi-crashes can be regarded to be sourced by high speed which made a crashed vehicle to bounce into barriers. Examples have been elucidated in Section 5 paragraph 3. In addition to that, various types of barriers and crash positions were involved. However, simulating a multi-crashes test could be a bit challenging in terms of crash speed, barriers, and assessment of safety criteria. A proper matrix that combines an appropriate crash speed, number, and type of barriers to be used and crash positions needs attention to carefully address the above parameters.

\subsection{Types of Barriers}

The main barriers involved in many of the reported real-world EVs' incidents have been explained in Section 5 paragraph 6. However, two major challenges have been raised regarding the barriers. First, the issue of round poles to split the EV when slammed at high speed. Some incidents have been reported in incident no. 4 and 48 . Since slicing can occur from any EV side (front or side depending on the crash position), more enhancement is needed to strengthen the vehicle protection. Second, high possibility of moving barriers. 
In the pool of EV in the highway it is prone for vehicles to crash while in motion, hence it makes it possible to roll over.

\subsection{Injury Criteria}

The major challenge among the safety requirements presented in Section 3 is the protection of occupant against electric shock or fire/explosion from the damaged battery pack. Notably, the crash may compromise the electrical safety measures and elevate the risk of electric shock. To date, in the enhancement of safety technology many EVs are fixed with safety switch to isolate the high-voltage from the battery pack in the crash events. For example, the concept of safety switch has been introduced in Mitsubishi i-MiEV [7] and Mercedes-Benz hybrid and EVs [132]. Since the crash can confront the safety of battery itself and cause electrolyte leakage, UNECE R94 and R95 do not allow electrolyte spillage inside the passenger cabin. For leaking outside the cabin, electrolyte spillage is limited to 7\% (in UNECE R94 and R95) or 5 L maximum within 30 min only (in FMVSS 305), for open type of traction battery [132].

However, the new type of battery, LIB, employed in EVs, pose a serious safety concern due to their energetic and flammable materials, which are able to generate plenty of energy that can ignite a fire and later explode. The post-crash requirements for frontal and side impact tests permits the fuel leakage rate to $5 \times 10^{-4} \mathrm{~kg} / \mathrm{s}$, equivalent to $30 \mathrm{~g} / \mathrm{min}$ [132]. Nevertheless, these requirements may seem to not be compatible with LIB where the electrolyte vaporizes in air. LIB varies widely with chemistry having diverse quantities and constituents. Consequently, the resulted thermal and fire hazards after explosion may also depend on the battery chemistry. To improve the safety requirement due to battery pack explosion, this work is in-line with the suggestion provided in [132], that further research could be allowed to establish appropriate limits for different battery types.

\section{Summary and Future Outlook}

This paper focuses on the safety of the EVs and its occupants in the moments of crash incidents. The safety requirements from the regulations and safety programs and recent research reviewed and later compared with the real-world fire incidents. The key outcomes can be summarized as follows:

- Most of EVs are designed using conventional vehicle design strategies such as body frame and chassis and an inclusion of electrified powertrain and energy storage system. Replacing the internal combustion engine with an electrified drivetrain in the front compartment, the addition of heavy battery pack, and structural modification necessitates the need of exploring the crash behavior of EVs. Currently, crashworthiness defines the ability of the vehicle structure to sufficiently protect the occupant against body injury (mechanical hazard) only, without including thermal and fire hazards.

Energy storage system is the heart of the EV and its safety issues pose risk to the whole vehicle. In amid of EV uptrend, LIB technology has gained popularity but its safety concern has raised much attention. For successful applications in EVs, the requirements of international standards, national standards, regulations, and other laboratories have been reviewed. Moreover, the requirements for the safety of occupants based on regulations and safety programs were elaborated.

The recent EVs' fire incidents were compared with the safety requirements outlined above. Several challenges are reported including high impact speed, multi-crashes per incident, multiple barriers of different types involved in the incident, and post-crash safety (extreme injury and demise) of occupants were evaluated.

For improving the crashworthiness, in the future, the EV models need to be well advanced in the following areas:

Isolation of high-voltage in the moment of crashing to protect the first and second responders of different EV models.

Possibility of externally discharging the electrical energy stored in battery pack of the slammed EV. 
Enhancing the battery technology by replacing the flammable and toxic materials with safer ones. Due to the serious mechanical damages posed on the battery pack during the crash, understanding the failure process and damage tolerance of the battery becomes crucial in the future. That knowledge is important for designing a safe battery pack for an EV. The gap of knowledge regarding the mechanism of battery reaction to crush loading with electrical, chemical, and thermal behavior.

Strengthening the battery pack enclosure not to burn easily and allow no fumes to penetrate in the cabin. Moreover, severe crashes in the field are still deforming the battery pack in the crush-safe zone and lead to explosion. More effort should be focused on strengthening the side area reinforcement as it is challenging to offer crumple zones around. The critical parameters to be focused include energy absorption capability in sideways of the battery enclosure, arrangement of the battery enclosure and battery, effect of battery materials and crash response among adjacent batteries, and frame stiffness of the compartment. EV manufacturers and regulatory organizations are obliged to widen the studies of the vehicle structure, materials, and control systems in order to attain higher ranking.

$\bigcirc \quad$ Acquiring the real-time vehicle information and incorporating them with an outgoing call of the vehicle's advanced automatic collision notification (AACN) system for accurate identification of the source toward the crash incident.

To encourage large number of real crash experiments and incorporating the observed real-world crash phenomena in order to develop inclusive test procedures and evaluation techniques which will be useful for examining the crash safety of EVs and develop appropriate safety regulations for the EVs. Current crash regulations for EVs are a virtuous starting point for establishing new ones.

In the near future, small light EVs (SLEVs) are expected to increase significantly and emerge as a future solution especially in urban mobility. The major reason is their small physical dimensions. The attributes of SLEVs include short front and rear overhang and occupying less than 5 passengers. Their crash characteristics must be well understood to ensure the sufficient safety of SLEVs in the EV crash regulations. Furthermore, the obstacle to the broader commercialization, acceptance, and further growth of SLEVs is the current regulatory fragmentation which does not consider the crash safety of SLEVs.

\section{Conclusions}

Currently, EVs have become the green transport by saving the globe from imminent catastrophes caused by global warming. However, with the steady growth of the automotive industry, EVs pose a questionable issue regarding the safety. The key areas that are prominent in the crashworthiness of EVs have been presented and elaborated. The serious challenges observed include high impact speed, multi-crashes per incident, multiple barriers of different types involved in the accident, and post-crash safety (serious injury and demise) of occupants and rescue teams. While addressing these challenges, this review will aid researchers, engineers and manufacturers working in EVs, and fire safety engineering to narrow the gap and enhance the safety of future EVs in areas of battery, fire extinguishing, and vehicle's body structure. To conclude, this paper has provided a clear picture on the safety of EVs and occupants and potential areas that are in need of further research.

Author Contributions: Conceptualization and writing-original draft preparation, P.V.C.; investigation, writing - review and editing, visualization, supervision, Y.L. and S.W.; funding acquisition, S.W. All authors have read and agreed to the published version of the manuscript.

Funding: National Science and Technology Development Agency (NSTDA).

Institutional Review Board Statement: Not applicable.

Informed Consent Statement: Informed consent was obtained from all subjects involved in the study. 
Data Availability Statement: Data sharing is not applicable to this article.

Acknowledgments: The authors would like to express their gratitude to The Joint Graduate School of Energy and Environment, KMUTT. The third author acknowledges the financial support provided by the "Research Chair Grant" National Science and Technology Development Agency (NSTDA).

Conflicts of Interest: The authors declare no conflict of interest.

\section{References}

1. Sinz, W.; Feist, F.; Gstrein, G.; Gugler, J.; Tomasch, E.; Breitfuss, C.; Luttenberger, P.; Steffan, H. Concept of Mechanical Abuse Testing of High-Voltage Batteries; SAE Technical Paper 2012-01-0124; Society of Automobile Engineers: Warrendale, PA, USA, 2012. [CrossRef]

2. Tomšić, Ž.; Raos, S.; Rajšl, I.; Ilak, P. Role of electric vehicles in transition to low carbon power system-Case study Croatia. Energies 2020, 13, 6516. [CrossRef]

3. Miri, I.; Fotouhi, A.; Ewin, N. Electric vehicle energy consumption modelling and estimation-A case study. Int. J. Energy Res. 2021, 45, 501-520. [CrossRef]

4. Foley, A.; Winning, I.; Gallachóir, B.Ó. Electric vehicles: Infrastructure regulatory requirements. In Proceedings of the Inaugural Conference of the Irish Transport Research Network, Dublin, Ireland, 31 August-1 September 2010.

5. Erd, A.; Stoklosa, J. Energy dependencies in li-ion cells and their influence on the safety of electric motor vehicles and other large battery packs. Energies 2020, 13, 6738. [CrossRef]

6. Cerdas, F.; Titscher, P.; Bognar, N.; Schmuch, R. Exploring the effect of increased energy density on the environmental impacts of traction batteries: A comparison of energy-optimized Lithium-ion and Lithium-Sulfur batteries for mobility applications. Energies 2018, 11, 150. [CrossRef]

7. Uwai, H.; Isoda, A.; Ichikawa, H.; Takahashi, N. Development of body structure for the crash safety of the newly developed electric vehicle. In Proceedings of the 22nd International Conference on the Enhanced Safety of Vehicles, Washington, DC, USA, 13-16 June 2011. Paper Number 11-0199.

8. IEA. Global EV Outlook. 2020. Available online: https://www.iea.org/reports/global-ev-outlook-2020 (accessed on 14 January 2021).

9. Bloomberg NEF. Electric Vehicle Outlook. 2020. Available online: https://about.bnef.com/electric-vehicle-outlook/ (accessed on 14 January 2021).

10. Feng, X.; Ouyang, M.; Liu, X.; Lua, L.; Xia, Y.; He, X. Thermal runaway mechanism of lithium ion battery for electric vehicles: A review. Energy Storage Mater. 2018, 10, 246-267. [CrossRef]

11. C40 Cities. Consumption-Based GHG Emissions of C40 Cities. Available online: https://www.c40.org/researches/consumptionbased-emissions (accessed on 14 January 2021).

12. C40 Cities. Zero Emission Vehicles-C40. Available online: https://www.c40.org/networks/zero-emission-vehicles (accessed on 14 January 2021).

13. Urban Access Regulation in Europe. Available online: https://urbanaccessregulations.eu/low-emission-zones-main/what-arelow-emission-zones (accessed on 14 January 2021).

14. Chombo, P.V.; Laoonual, Y. A review of safety strategies of a Li-ion battery. J. Power Sources 2020, 478, 228649. [CrossRef]

15. Sun, P.; Bisschop, R.; Niu, H.; Huang, X. A review of battery fires in electric vehicles. Fire Technol. 2020, 56, 1361-1410. [CrossRef]

16. Kong, L.; Li, C.; Jiang, J.; Pecht, M.G. Li-Ion battery fire hazards and safety strategies. Energies 2018, 11, 2191. [CrossRef]

17. Diaz, L.B.; He, X.; Hu, Z.; Restuccia, F.; Marinescu, M.; Barreras, J.V.; Patel, Y.; Offer, G.; Rein, G. Meta-review of fire safety of lithium-ion batteries: Industry challenges and research contributions. J. Electrochem. Soc. 2020, 167, 090559. [CrossRef]

18. Khan, S.; Arambulo, A. Officers Injured, Stolen Tesla Split in Half after Fiery Pursuit Wreck. Available online: https://www nbclosangeles.com/news/local/Stolen-Tesla-High-Speed-Chase-Fiery-Crash-in-West-Hollywood-265813821.html (accessed on 14 January 2021).

19. Wilcox, G. Man Who Died in Fiery Malibu Canyon Crash of Tesla Is 53- Year-Old from Calabasas. Available online: https://www. dailynews.com/2015/06/23/man-who-died-in-fiery-malibu-canyon-crash-of-tesla-is-53-year-old-from-calabasas/ (accessed on 14 January 2021).

20. Revill, J.; Stamp, D. Tesla Crash May Have Triggered Battery Fire: Swiss Firefighters. Available online: https://www.reuters. $\mathrm{com} /$ article/us-swiss-tesla-crash/tesla-crash-may-have-triggered-battery-fire-swiss-firefighters-idUSKCN1IF2WN (accessed on 14 January 2021).

21. Levin, A. Tesla that Caught Fire in Florida Crash Reached 116 mph. Available online: https://www.bloomberg.com/news/ articles / 2018-06-26/tesla-model-s-that-caught-fire-in-florida-hit-speed-of-116-mph (accessed on 14 January 2021).

22. Shepardson, D.; Shivdas, S.U.S. Safety Board Probes Fatal Tesla Accident in Florida. 2018. Available online: https://www.reuters. com/article/us-tesla-crash/two-killed-in-tesla-car-crash-in-florida-police-idUSKBN1IA205 (accessed on 14 January 2021).

23. Carolyn, F. Two Killed after Tesla Crashes into a Tree at High Speed. 2016. Available online: https://www.teslarati.com/twolives-lost-tesla-high-speed-crash-indianapolis / (accessed on 14 January 2021).

24. Doney, D. Was Mountain View Tesla Crash a Failure of Autopilot, Automatic Braking Systems? Available online: https://abc7 news.com/automotive/was-bay-area-tesla-crash-failure-of-autopilot-braking-systems/3575773/ (accessed on 14 January 2021). 
25. Sterling, T. Dutchman Dies in Tesla Crash; Firefighters Feared Electrocution. 2016. Available online: https://www.reuters.com/ article/us-tesla-netherlands-idUSKCN11D28Z (accessed on 14 January 2021).

26. ChinaAutoWeb. Three BYD e6 Passengers Killed in Fiery Crash, Spurring EV Safety Concern. Available online: http: // chinaautoweb.com/2012/05/three-byd-e6-passengers-killed-in-fiery-crash-spurring-ev-safety-concern/ (accessed on 14 January 2021).

27. Isidore, C. Are Electric Cars More Likely to Catch Fire? Available online: https://money.cnn.com/2018/05/17/news/companies/ electric-car-fire-risk/index.html (accessed on 23 April 2021).

28. AirQualityNews.com. Electric Vehicle Fires-Should We Be Concerned? Available online: https://airqualitynews.com/2020/10/ 09/electric-vehicle-fires-should-we-be-concerned/ (accessed on 23 April 2021).

29. Navale, A.B.; Chippa, S.P.; Chougule, D.A.; Raut, P.M. Crashworthiness aspects of electric vehicle design. Int. J. Crashworthiness 2020, 26, 368-387. [CrossRef]

30. Liu, Q.; Lin, Y.; Zong, Z.; Sun, G.; Li, Q. Lightweight design of carbon twill weave fabric composite body structure for electric vehicle. Compos. Struct. 2013, 97, 231-238. [CrossRef]

31. Yu, L.; Gu, X.; Qian, L.; Jiang, P.; Wang, W.; Yu, M. Application of tailor rolled blanks in optimum design of pure electric vehicle crashworthiness and lightweight. Thin Wall Struct. 2021, 161, 107410. [CrossRef]

32. Science Focus. Do Crashed Electric Vehicles Pose a Fire. Available online: https://www.sciencefocus.com/science/do-crashedelectric-vehicles-pose-a-fire-or-electrocution-risk/ (accessed on 24 July 2021).

33. O'Malley, S.; Zuby, D.; Moore, M.; Paine, M.; Paine, D. Crashworthiness testing of electric and hybrid vehicles. In Proceedings of the 24th International Technical Conference on the Enhanced Safety of Vehicles, Gothenburg, Sweden, 8-11 June 2015.

34. Warner, J. Lithium-ion battery packs for EVs. In Lithium-Ion Batteries; Elsevier: Amsterdam, The Netherlands, 2014; pp. 127-150. [CrossRef]

35. SAE J2464: Electric and Hybrid Electric Vehicle Rechargeable Energy Storage System (RESS) Safety and Abuse Testing; Society of Automotive Engineers (SAE): Warrendale, PA, USA, 2009.

36. SAE J2929: Electric and Hybrid Vehicle Propulsion Battery System Safety Standard-Lithium-Based Rechargeable Cells; Society of Automotive Engineers (SAE): Warrendale, PA, USA, 2011.

37. ISO 124045-1: Electrically Propelled Road Vehicles-Test Specification for Lithium-Ion Traction Battery Packs and Systems-Part 1: High-Power Applications; International Organization for Standardization (ISO): Geneva, Switzerland, 2011.

38. ISO 124045-2: Electrically Propelled Road Vehicles-Test Specification for Lithium-Ion Traction Battery Packs and Systems-Part 2: High-Energy Applications; International Organization for Standardization (ISO): Geneva, Switzerland, 2012.

39. ISO 124045-3: Electrically Propelled Road Vehicles-Test Specification for Lithium-Ion Traction Battery Packs and Systems-Part 3: Safety Performance Requirements; International Organization for Standardization (ISO): Geneva, Switzerland, 2014.

40. IEC 62660-1: Secondary Lithium-Ion Cells for The Propulsion of Electric Road Vehicles-Part 1: Performance Testing; International Electrotechnical Commission: Geneva, Switzerland, 2018.

41. IEC 62660-2: Secondary Lithium-Ion Cells for The Propulsion of Electric Road Vehicles_Part 2: Reliability and Abuse Testing; International Electrotechnical Commission: Geneva, Switzerland, 2018.

42. IEC 62660-3: Secondary Lithium-Ion Cells for The Propulsion of Electric Road Vehicles-Part 3: Safety Requirements; International Electrotechnical Commission: Geneva, Switzerland, 2016.

43. UN/ECE Regulation No. 100.02: Uniform Provisions Concerning the Approval of Vehicles with Regard to Specific Requirements for the Electric Power Train; Economic Commission for Europe of the United Nations (UNECE): Geneva, Switzerland, 2015.

44. UL 2508: Batteries for Use in Electric Vehicles; UL Standards: Northbrook, IL, USA, 2020.

45. Ruiz, V.; Pfrang, A.; Kriston, A.; Omar, N.; van den Bossche, P.; Boon-Brett, L. A review of international abuse testing standards and regulations for lithium ion batteries in electric and hybrid electric vehicles. Renew. Sust. Energ. Rev. 2018, 81, 1427-1452. [CrossRef]

46. KMVSS Article18-3: Traction Battery (RESS); Korea Motor Vehicle Safety Standard (KMVSS): Sejong-si, Korea, 2009.

47. AIS-048: Battery Operated Vehicles—Safety Requirements of Traction Batteries; Automotive Industry Standard: Pune, India, 2009.

48. QC/T 743: Lithium-Ion Batteries for Electric Vehicles; China Plan Publishing Company, China. 2006. Available online: https: //www.chinesestandard.net/PDF.aspx/QCT743-2006 (accessed on 23 July 2021).

49. GB 38031: Electric Vehicles Traction Battery Safety Requirements; Guobiao Standards: Shenzhen, China, 2020.

50. Brandt, K.; Garche, J. Chapter 1-General Battery Safety Considerations. In Electrochemical Power Sources: Fundamentals, Systems, and Application; Li-Battery Safety; Elsevier: Amsterdam, The Netherlands, 2019; pp. 1-19.

51. Euro NCAP: The European New Car Assessment Program: Leuven, Belgium. 1996. Available online: https://www.euroncap. com/en (accessed on 23 July 2021).

52. US NCAP: The US New Car Assessment Program: National Highway Traffic Safety Administration, Washington, DC, USA. 1979. Available online: https:/ / www.nhtsa.gov/ (accessed on 23 July 2021).

53. Latin NCAP: Latin New Car Assessment Program, Montevideo, Uruguay. 2010. Available online: https://www.latinncap.com/ en/ (accessed on 23 July 2021).

54. JNCAP: Japan New Car Assessment Program, Tokyo, Japan. 1995. Available online: https://www.nasva.go.jp/ (accessed on 23 July 2021). 
55. ASEAN NCAP: New Car Assessment Program for Southeast Asian Countries, Kajang, Selangor, Malaysia. 2011. Available online: https: / / aseancap.org/v2/ (accessed on 23 July 2021).

56. CNCAP: China New Car Assessment Program, Tianjin, China. 2006. Available online: http://www.c-ncap.org/ (accessed on 23 July 2021).

57. UN/ECE Regulation No. 94: Uniform Provisions Concerning the Approval of Vehicles with Regard to the Protection of the Occupants in the Event of a Frontal Collision; Economic Commission for Europe of the United Nations (UNECE): Geneva, Switzerland, 2012.

58. UN/ECE Regulation No. 95: Uniform Provisions Concerning the Approval of Vehicles with Regard to the Protection of the Occupants in the Event of a Lateral Collision; Economic Commission for Europe of the United Nations (UNECE): Geneva, Switzerland, 2015.

59. GB 11551: The Protection of the Occupants in the Event of a Frontal Collision for Motor Vehicle; Guobiao Standards: Shenzhen, China, 2014.

60. GB 20071: The Protection of the Occupants in the Event of a Lateral Collision; Guobiao Standards: Shenzhen, China, 2006.

61. FMVSS 208: Occupant Crash Protection; Federal Motor Vehicle Safety Standards (FMVSS): Washington, DC, USA, 2006.

62. FMVSS 214: Side Impact Protection; Federal Motor Vehicle Safety Standards (FMVSS): Washington, DC, USA, 2010.

63. FMVSS 301: Fuel System Integrity; Federal Motor Vehicle Safety Standards (FMVSS): Washington, DC, USA, 2005.

64. Wissenbaum. Global Automotive Safety Regulations in a Nutshell. 2015. Available online: https://www.team-bhp.com/ forum/attachments / road-safety / 1505831d1462895342-more-indian-cars-face-global-ncap-crash-tests-edit-zero-all-globalautomotive-safety-regulations-nutshell.pdf (accessed on 14 January 2021).

65. Ujihashi, S. Introduction of JNCAP and the comparison with Euro NCAP. In Proceedings of the 5th ANSA \& $\mu$ ETA International Conference, Thessaloniki, Greece, 5-7 June 2013.

66. Palvoelgyi, S.; Stangl, P.K. Electric Vehicle Technology. Crashworthiness of the Electric G-van; SAE Technical Paper 900579; Society of Automotive Engineers (SAE): Warrendale, PA, USA, 1990; pp. 99-105. [CrossRef]

67. EVERSAFE. Recommendations and Guidelines for Battery Crash Safety and Post-Crash Safe Handling. Available online: https: / / www.diva-portal.org/smash/get/diva2:1367933/FULLTEXT01.pdf (accessed on 23 July 2021).

68. Polestar. Polestar 2's First Crash Test. The Crash Labs Are Installing a Pool. Available online: https://www.polestar.com/us/ news/polestar-2-s-first-crash-test/ (accessed on 23 January 2021).

69. Scullion, P.; Morgan, R.M.; Digges, K.; Kan, C.-D. Frontal Crashes between the Longitudinal Rails. Paper Number 11-0372. Available online: https:/ / www-esv.nhtsa.dot.gov/Proceedings/22/files/22ESV-000372.pdf (accessed on 23 January 2021).

70. Ispas, N.; Nastasoiu, M. Analysis of car's frontal collision against pole. In IOP Conference Series: Materials Science and Engineering; IOP Publishing: Bristol, UK, 2017; Available online: https://iopscience.iop.org/article/10.1088/1757-899X/252/1/012012/pdf (accessed on 23 January 2021).

71. Munyazikwiye, B.B.; Vysochinskiy, D.; Khadyko, M.; Robbersmyr, K.G. Prediction of vehicle crashworthiness parameters using piecewise lumped parameters and finite element models. Designs 2018, 2, 43. [CrossRef]

72. Syuhri, A. Design and modeling of hydraulic crash damper in a racing electric vehicle. Int. J. Mech. Mechatron. 2016, 16, 166-172.

73. Klausen, A.; Tørdal, S.S.; Karimi, H.R.; Robbersmyr, K.G.; Ječmenica, M.; Melteig, O. Mathematical Modeling and Numerical Optimization of Three Vehicle Crashes Using a Single-Mass Lumped Parameter Model; Paper Number: 15-0168. Available online: https: / / www-esv.nhtsa.dot.gov / Proceedings/24/files/24ESV-000168.PDF (accessed on 23 January 2021).

74. Belingardi, G.; Obradovic, J. Design of the impact attenuator for a formula student racing car: Numerical simulation of the impact crash test. J. Serbian Soc. Comput. Mech. 2010, 4, 52-65.

75. Arifin, Z.; Gunawan, S. Design and testing impact attenuator of formula SAE FG17 Garuda UNY car. J. Phys. Conf. Ser. 2019, 1387, 012091. [CrossRef]

76. Zhang, S.A.; Zhou, Q.; Xia, Y. Influence of wheels on frontal crash response of small lightweight electric vehicle. In Proceedings of the ASME 2015 International Mechanical Engineering Congress and Exposition, Houston, TX, USA, 13-19 November 2015; Volume 12: Transportation Systems. [CrossRef]

77. Roland, U.; Karthik, A.S.; Tjorben, B.; Thomas, V. Finite element analysis considering packaging efficiency of innovative battery pack designs. Int. J. Crashworthiness 2019, 25, 664-679.

78. Li, Z.; Duan, L.B.; Cheng, A.G.; Yao, Z.P.; Chen, T.; Yao, W. Lightweight and crashworthiness design of an electric vehicle using a six-sigma robust design optimization method. Optim. Eng. 2019, 51, 1393-1411. [CrossRef]

79. Chen, Y.; Cheng, X.; Fu, K. Multi-material design of a vehicle body considering crashworthiness safety and social effects. Int. J. Crashworthiness 2019, 25, 517-526. [CrossRef]

80. Schäffer, M.; Münster, M.; Sturm, R.; Friedrich, H.E. Development of an optimized side crash concept for the battery-electric vehicle concept Urban Modular Vehicle. In Proceedings of the LS-DYNA Forum 2016, Bamberg, Germany, 10-12 October 2016.

81. Hao, F.; Lu, X.; Qiao, Y.; Chen, X. Crashworthiness analysis of electric vehicle with energy-absorbing battery modules. J. Eng. Mater. Technol. 2017, 139, 021022. [CrossRef]

82. Setiawan, R.; Salim, M.R. Crashworthiness design for an electric city car against side pole impact. J. Eng. Technol. Sci. 2017, 49, 587-603. [CrossRef]

83. Zhang, J.; Ning, L.; Hao, Y.; Sang, T. Topology optimization for crashworthiness and structural design of a battery electric vehicle. Int. J. Crashworthiness 2020, 25, 1-10. [CrossRef]

84. Krisher, T.; Baker, M. Tesla says car fire began in battery after crash. The Seattle Times 3 October 2013. Available online: https:/ / www.seattletimes.com/business/tesla-says-car-fire-began-in-battery-after-crash/ (accessed on 25 January 2021). 
85. Klayman, B.; Woodall, B. UPDATE 5-Tesla reports third fire involving model S electric car. Reuters 7 November 2013. Available online: https:/ / www.reuters.com/article/autos-tesla-fire-idUSL2N0IS0TL20131107 (accessed on 25 July 2021).

86. Mail Online. PICTURED: Young Bride-To-Be, 27, and Her Tech Entrepreneur Boss, 44, Who Were Killed When the Tesla They Were Driving Slammed into a Tree and Burst into a FIREBALL. Available online: https://www.dailymail.co.uk/news/article-39 08700/Two-people-killed-Tesla-crash-Indianapolis.html (accessed on 27 January 2021).

87. City News Service. Tesla Crashes into Lake Forest Home, Igniting Fire. Available online: https://www.nbclosangeles.com/ news / tesla-lake-forest-home-fire/22740/ (accessed on 27 January 2021).

88. Best. Terrifying Moment 35 Firefighters Struggle to Tackle an Enormous Blaze after a Tesla Model S Crashes in Austria and Turns into an INFERNO. Available online: https:/ / www.dailymail.co.uk/sciencetech/article-4997486/35-firefighters-tackle-enormousTesla-Model-S-fire.html (accessed on 27 January 2021).

89. Brown, B. Tesla Says Driver Ignored Warnings from Autopilot in Fatal California Crash. Available online: https://www. digitaltrends.com/cars/tesla-autopilot-fatal-crash-warnings-ignored/ (accessed on 27 January 2021).

90. South China Moning Post. The Car Lost Control, Struck a Wall, Rebounded into Another Wall and Erupted in Flames before Reigniting Twice, a US Government Report Said. Available online: https:/ /www.scmp.com/news/world/united-states-canada/ article/2152644/tesla-model-s-caught-fire-florida-hit-speed-116-mph (accessed on 27 January 2021).

91. Winkler, S. Final Report-Crash Involving Tesla Model S-10400 South Bangerter Highway. South Jordan Police Department. Available online: https:/ /gephardtdaily.com/local/south-jordan-police-release-report-on-tesla-that-crashed-while-in-autopilot/ (accessed on 27 January 2021).

92. Bisschop, R.; Willstrand, O.; Amon, F.; Rosengren, M. Fire Safety of Lithium-Ion Batteries in Road Vehicles. 2019. Available online: http:/ / www.diva-portal.org/smash/get/diva2:1317419/FULLTEXT02.pdf (accessed on 27 January 2021).

93. Zafar, R. Tesla Responds to Model X Explosion in China; Denies 'Outrageous' Owner Claims. Available online: https:/ /wccftech. com/tesla-responds-to-vehicle-explosion-in-china/ (accessed on 27 January 2021).

94. RT. 3 Injured as Tesla Goes Up in Flames \& Explodes on Moscow Freeway (VIDEOS). Available online: https: / /www.rt.com/ russia/466247-tesla-blast-moscow-injured/ (accessed on 27 January 2021).

95. Charlier, P. Tesla Catches Fire after Crash: Driver Dies. Available online: https://taiwanenglishnews.com/tesla-catches-fire-aftercrash-driver-dies / (accessed on 27 January 2021).

96. Ingram, A. Stolen Tesla model S involved in multi-car wreck in West Hollywood. Green Car Reports 4 July 2014. Available online: https:/ / www.greencarreports.com/news/1093126_stolen-tesla-model-s-involved-in-multi-car-wreck-in-west-hollywood (accessed on 27 January 2021).

97. Brown, B. Tesla Model S Driver Crashes and Dies in Fire, Responders Couldn't Open Doors. Digitaltrends 26 February 2019. Available online: https:/ / www.digitaltrends.com/cars/tesla-model-s-driver-dies-in-fire-door-handles-fail/ (accessed on 27 January 2021).

98. Borcia, S. Tesla SUV Catches on Fire after Head-on Crash in Barrington. Available online: https:/ / www.lakemchenryscanner. com/2019/12/19/tesla-suv-catches-on-fire-after-head-on-crash-in-barrington/ (accessed on 27 January 2021).

99. Abramoff, M. Tesla Catches Fire, 12 Tons of Water Used to Extinguish It. Available online: https://www.minareport.com/2019/1 0/06/13055/ (accessed on 27 January 2021).

100. Klender, J. Tesla Autopilot under Fire Once more from US Senator Following Accident. Available online: https:/ /www.teslarati. com/tesla-autopilot-ban-us-senator-doubles-down-after-collision/ (accessed on 27 January 2021).

101. Loveday, E. Tesla Model X Driver Survives Horrific Crash, Fire: Video. Available online: https://insideevs.com/news/342898 / tesla-model-x-driver-survives-horrific-crash-fire-video/ (accessed on 27 January 2021).

102. Louie, D. Fiery Tesla Model X Crash in Fremont Leaves Driver Injured. Available online: https://abc7news.com/paseo-padreparkway-fremont-tesla-crash-on-car-fire/5143718/ (accessed on 27 January 2021).

103. Loveday, E. Watch Tesla Model X Crash Again and Again in Wild Series of Accidents. Available online: https://insideevs.com/ news /365669/video-tesla-model-x-crashes/ (accessed on 27 January 2021).

104. De Feijter, T. First Tesla Autopilot Crash in China. Available online: https:/ / carnewschina.com/2016/08/05/first-tesla-autopilotcrash-in-china/ (accessed on 27 January 2021).

105. De Feijter, T. First Tesla Crashes in China. Available online: https://carnewschina.com/2014/07/11/first-tesla-crashes-in-china / (accessed on 27 January 2021).

106. Lambert, F. Video of Tesla Model 3 Crashing into a Truck on Autopilot Goes Viral. Available online: https://electrek.co/2020/0 6/01/tesla-model-3-crashing-truck-autopilot-video-viral/ (accessed on 27 January 2021).

107. Fox, E. Tesla Model X Superior Safety Once again Proven in Unfortunate Accident. Available online: https://www.tesmanian. com/blogs/tesmanian-blog/model-x (accessed on 27 January 2021).

108. Ning, W.E. Tesla Model X Crashes into a Tree in China, Penetrated by Guardrail. Available online: https:/ / carnewschina.com/20 17/03/27/tesla-model-x-crashes-into-a-tree-in-china-penetrated-by-guardrail/ (accessed on 27 January 2021).

109. Loveday, E. Nissan LEAF Gets Totaled-Occupants Okay. Available online: https://insideevs.com/nissan-leaf-gets-totaledoccupants-okay (accessed on 27 January 2021).

110. HT Auto. Man in Horror Tesla Crash Walks out Unscathed, Vows to Buy Same EV Again. Available online: https: / / auto.hindustantimes.com/auto/news/man-in-horror-tesla-crash-walks-out-unscathed-vows-to-buy-same-ev-again-4160 1693002647.html (accessed on 27 January 2021). 
111. Banks, I. Tesla Model 3 Saves Family from Serious Injury after Being Rear-Ended at High Speed. Available online: https: //www.teslarati.com/tesla-model-3-family-safety-rear-end-collision/ (accessed on 27 January 2021).

112. Loveday, S. Driver Walks Away Unharmed after Big Rig Rear Ends Tesla Model S. Available online: https://insideevs.com/ news/332164/driver-walks-away-unharmed-after-big-rig-rear-ends-tesla-model-s/ (accessed on 27 January 2021).

113. Loveday, S. Watch Tesla Model 3 Get Forcefully Rear-Ended by Honda Civic. Available online: https://insideevs.com/news/37 9871/video-tesla-rear-end-crash-footage/ (accessed on 27 January 2021).

114. Holland, C. Tesla Rear-Ends DPS Vehicle, Pushes It into Ambulance on I-10 Near Benson. Available online: https: / / www.azfamily.com/news/tesla-rear-ends-dps-vehicle-pushes-it-into-ambulance-on-i-10-near-benson/article_06487d26-c6 15-11ea-b0ca-ab09abc88227.html (accessed on 27 January 2021).

115. Hanley, S. Adam Levine's Tesla Model X Gets Rear-Ended by Ferrari. Available online: https://www.teslarati.com/adamlevines-tesla-model-x-gets-rear-ended-ferrari/ (accessed on 27 January 2021).

116. Alvarez, S. Tesla Model X Driver Shares Unbelievable Story of DEA Plane Crashing into Car. Available online: https://www. teslarati.com/tesla-model-x-dea-airplane-crash/ (accessed on 27 January 2021).

117. Auto Spies. WATCH: TeslaCam Catches the Moments Up to and after Crash. Available online: https: / www.autospies.com/ news / WATCH-TeslaCam-Catches-The-Moments-Up-To-And-After-Crash-101958/ (accessed on 27 January 2021).

118. Wang, J. Tesla Model X Hits Van in China, Autopilot Blamed. Available online: https://carnewschina.com/2017/03/09/teslamodel-x-hits-van-in-china-autopilot-blamed/ (accessed on 27 January 2021).

119. Tanno, S. Tesla Model X Is Torn in Two after Horror Smash When Another Driver 'Runs a Red Light' at Florida Intersection-But Miraculously Nobody Is Killed. Available online: https:/ / www.dailymail.co.uk/news/article-7916553/Tesla-Model-X-cut-halfdebris-scattered-highway.html (accessed on 27 January 2021).

120. Inspiration Revolution. Tesla Model X CRAZY Crash, Cut \& Split in Half by Speeding Nissan GTR-Greg Ferreira. Available online: https: / / www.youtube.com/watch?v=tmczzdPqPus (accessed on 27 January 2021).

121. Kimberley, M. Another Tesla Autopilot Crash Has Wrecked a Model 3 in Greece. Available online: https:/ /www.carthrottle.com/ post/another-tesla-autopilot-crash-has-wrecked-a-model-3-in-greece/ (accessed on 27 January 2021).

122. Klender, J. Tesla Owner Shares Insights after Model 3 Protects Him from Violent High-Speed Crash. Available online: https: / / www.teslarati.com/tesla-model-3-owner-high-speed-truck-collision/ (accessed on 27 January 2021).

123. Alvarez, S. Tesla Model S Driver Walks Away from Violent Head-On Collision Caught on Video. Available online: https: / / www.teslarati.com/tesla-model-s-collision-spain-video/ (accessed on 27 January 2021).

124. The NewsWheel. Hundreds of Maserati Cars Destroyed in Fire in Italy. Available online: https://thenewswheel.com/hundredsof-maserati-cars-destroyed-in-fire-in-italy/ (accessed on 27 January 2021).

125. Reuters. Swiss Prosecutors Investigate Fatal Tesla Crash, Suspect 'Thermal Runaway' of Battery. Available online: https:/ / www.japantimes.co.jp/news/2018/05/17/business/swiss-prosecutors-investigate-fatal-tesla-crash-suspect-thermalrunaway-battery/ (accessed on 27 January 2021).

126. Deveza, C. Tesla Passengers Survive Rollover Thanks to MIC Model 3's Tough Roof. Available online: https://www.tesmanian. com/blogs/tesmanian-blog/tesla-mic-model-3-accident-roof (accessed on 27 January 2021).

127. Rogers, S. Model 3 Rolls over in Wreck but Sustains 'Minimal' Damage. Available online: https: / interestingengineering.com/ model-3-rolls-over-in-wreck-but-sustains-minimal-damage (accessed on 27 January 2021).

128. Hruska, J. Fisker Auto Founders, Fires Furloughed Employees, Preps for Bankruptcy. Available online: https: / / www.extremetech. com/extreme/152893-fisker-auto-founders-fires-furloughed-employees-preps-for-bankruptcy (accessed on 27 January 2021).

129. Porsche. Taycan Turbo S. Available online: https://www.porsche.com/international/models/taycan/taycan-models/taycanturbo-s / (accessed on 29 January 2021).

130. Tesla. Model S Plaid. Available online: https:/ / www.tesla.com/en_eu/models (accessed on 29 January 2021).

131. Electric Vehicle Database. Nissan LEAF. Available online: https://ev-database.org/car/1106/Nissan-Leaf (accessed on 29 January 2021).

132. Justen, R.; Schöneburg, R. Crash safety of hybrid- and battery electric vehicles. In Proceedings of the 22nd International Technical Conference on the Enhanced Safety of Vehicles, Washington, DC, USA, 13-16 June 2011; Paper No. 11-0096; National Highway Traffic Safety Administration (NHTSA): Washington, DC, USA, 2011. 